Itinera Spiritualia

IX $\cdot 2016 \cdot 105-152$

\title{
KU FILOZOFII PRZYJAŹNI. W DIALOGU Z PLATONEM, ARYSTOTELESEM I ŚW. TERESĄ OD JEZUSA
}

\section{W PROWADZENIE}

Zagadnienie przyjaźni jest jednym z najbardziej inspirujących i płodnych tematów, jakich dostarcza nam życie. Nie ma chyba człowieka, który nie interesowałby się przyjaźnią i nie pragnął jej. Każdy też ma jaką́s własną filozofię na jej temat.

Rzecz w tym, że większość tych domorosłych filozofii, aczkolwiek początkowo naznaczonych pełnym pasji myśleniem i niezwylkle obiecujących dla jednostki i społeczeństwa, niestety nie osiaga wszystkich swoich możliwości, to znaczy nie odpowiada na pytanie o is to tę przyjaźni -czym ona jest $\mathrm{i}$ jakie formy może przyjąć w konkretnym życiu. W konsekwencji - nie spełnia pokładanych w nich nadziei na zbudowanie wspólnoty pomiędzy ludźmi. Wiele z owych filozofii popada $w$ wewnętrzne sprzeczności, rozpływa się $\mathrm{i}$ bezpowrotnie ginie w odmętach szeroko rozlanych wód myślenia potocznego; im bardziej zbliża się do ujścia, tym większe wykazuje zanieczyszczenie oraz brak jakichkolwiek życiodajnych właściwości i ostatecznie ulega moralnemu sfrustrowaniu. Inne, jakby przy brzegach, na marginesie realnego życia, próbują tworzyć coś, co wprawdzie nosi imię przyjaźni, lecz wiodąca je myśl nie ukazuje żadnego wyższego celu (telos) i nie jest myślą uniwersalną; najczęściej pozostaje zamknięta w wirze własnych emocji, a wykreowane przez nią związki w rzeczywistości stanowią namiastki przyjaźni, zamknięte w sobie enklawy i towarzystwa wzajemnej adoracji.

Przywołane w podtytule artykułu imiona Platona (427-347 przed Chr.), Arystotelesa (384-322 przed Chr.) i św. Teresy od Jezusa (1515-1582) - wielkich filozofów starożytnej Grecji oraz hiszpańskiej mistyczki, reformatorki Zakonu karmelitańskiego i doktora Kościoła - budzą w nas jednak nowe uczucia i nowe zapały; budzą świadomość, że w naszych rozmyślaniach nie jesteśmy 
skazani na samych siebie i ciagłe dryfowanie po wodach tego świata. Są przy nas prawdziwi mistrzowie filozofowania, którzy wiedzą, co to znaczy przyjaźń. Nie są nihilistami. Pierwsi wyciągają przyjazną dłoń. Są gotowi prowadzić dialog i drążyć temat przyjaźni również z nami. Już sama ich obecność sprawia, że nabieramy otuchy i zaczynamy patrzeć na przyjaźń inaczej niż do tej pory. Otwarta zaś rozmowa, jaką prowadzą między sobą, wprost nas uskrzydla. Każda ich myśl to nowy promień światła i nowe zasoby sensu. Otwierają się bezkresne horyzonty. Coraz bardziej jesteśmy wciągani w ich orbitę...

Obojętnie jednak, jak potoczy się nasz dialog z nimi - wszakże jego jakość i owoce zawsze zależą od obu stron - zechciejmy na samym początku uświadomić sobie, że użyty w tytule artykułu rzeczownik „filozofia” ma takie znaczenie, jakie oni mu nadali, a nie takie, jakie my zwykle nadajemy mu w naszych czasach. W ich zaś rozumieniu refleksja filozoficzna, refleksja nad przyjaźnią, pozostaje zawsze w ścisłym związku z określoną formą życia, jest ożywiona przez życie i przekształca się w sposób życia, jest - jak powiedzieliby Grecy - logos i ergon jednocześnie, albo - jak z kolei powiedziałaby Hiszpanka - palabra i obra łącznie. Przyjęcie tej ich wizji filozofii jest ogromnie ważne. Przeciwny wybór bowiem natychmiast skutkuje tym, że „filozofia” spada do rangi „filologii”, a umiłowanie mądrości do umiłowania samych słów - przed czym przestrzegał już Seneka ${ }^{1}$.

Zauważmy ponadto, że rzeczownik „filozofia” nie został w tytule opatrzony żadnym przymiotnikiem, na przykład „chrześcijańska”; filozofia bowiem kieruje się własnymi metodami badawczymi i cieszy się autonomią w stosunku do wiary; nie potrzebuje żadnego dodatkowego dookreślenia. Takie dookreślenie nie musi być jednak błędem i czasami rzeczywiście bywa stosowane ${ }^{2}$. Ja również początkowo zamierzałem zatytułować ten artykuł „Ku chrześcijańskiej filozofii przyjaźni”, jako że w przypadku św. Teresy wkład wiary w rozwój jej myśli filozoficznej jest ogromny, a w pewnych aspektach decydujący. Ostatecznie jednak zrezygnowałem $z$ tego zamiaru.

Idąc w ślady autorów chrześcijańskich pierwszych wieków, którzy poganskiemu światu przedstawiali swoją religię jako filozofię i po prostu filozofię - vera et germana philosophia ${ }^{3}$ - postanowiłem w tym artykule uwydatnić terezjańską przyjaźń jako filozofię i po prostu filozofię, bez dodatkowych przymiotników. Wiemy oczywiście, że Teresa, mówiąc o przyjaźni, dysponuje

\footnotetext{
Por. L.A. Senera, Epistulae morales ad Lucilium, 14, 1; 20, 1-2.

Por. JaN PAWEe II, Fides et ratio, 49; 76.

Por. Augustyn, De Ordine, II, 5, 16. Zob. także określenie „una verissimae philosophiae disciplina" w: Contra Academicos, III, 19, 42; warto podkreślić, że według ojców Kościoła, szczególnie Bazylego z Cezarei, Grzegorza z Nyssy, Grzegorza z Nazjanzu, życie monastyczne, jako doskonalenie życia chrześcijanskiego, było po prostu filozofią. Nie wahali się również mówić, że jedynym prawdziwym Filozofem jest Chrystus
} 
pełnią objawienia Logosu (por. J 1, 1), natomiast Platon i Arystoteles mieli jedynie pewien jego zarys (spermatikos Logos, semina Verbi, ziarna Prawdy). W obu przypadkach jednak chodzi o ten sam Logos (Prawdę), o tę samą wewnętrzną strukturę ontologiczną i epistemologiczną. W obu przypadkach też - jak to już wyżej zostało powiedziane - prawdziwa "filozofia" nie jest jedynie zbiorem teoretycznych nauk czy jaką́s abstrakcyjną wizją rzeczywistości, lecz również sposobem bycia i formą egzystencji. Zarówno ro zumi en ie, jak i prze żywanie przyjaźni dokonuje się według Logosu.

W niniejszej pracy stawiam sobie za cel wprowadzenie $w$ dialog $z$ wyżej wspomnianymi architektami człowieczego życia i mistrzami filozofowania na temat przyjaźni. Przy ich pomocy chcę zwrócić uwagę na kilka starych, dzisiaj zapomnianych prawd, bez których jednak niemożliwe jest odkrycie istoty przyjaźni i w ogóle twórcze o niej myślenie. Chcę wskazać na przyjaźń jako formę życia i współistnienia ze sobą ludzi możliwą również w społeczeństwie pluralistycznym, w którym, $z$ powodu takich chorób moralnych, jak indywidualizm, subiektywizm, relatywizm, istnieje poważny niedobór communicatio idiomatum oraz ogromne zagrożenie ze strony religijnych i, jeszcze bardziej, świeckich „integralizmów" . W końcu chciałbym, aby była ona zachętą do dalszej refleksji na ten sam temat, ale już w obszarze ściśle teologicznym, a być może służyła również przygotowaniu do modlitwy, rozumianej jako „przyjacielskie obcowanie $z$ Bogiem" $(\dot{Z} 8,5)^{5}$.

W rozdziale pierwszym, historycznym, stawiam sam problem filozofii przyjaźni. Naświetlam go z perspektywy trzech różnych epok: nowożytnej, starożytnej i renesansowej. Wskazuję na konkretnych partnerów dziejowego dialogu w tejże kwestii: najpierw nas samych (teraźniejszość), następnie Platona i Arystotelesa (starożytność), i w końcu św. Teresę od Jezusa (renesans).

W rozdziale drugim, metafizycznym, odwołuję się do platońskiej teorii „idei”, w tym do idei przyjaźni, oraz do terezjańskiego rozumienia przyjaźni jako „daru”. Przy pomocy tych dwojga mistyków, należących do czasowo odległych, a duchowo bliskich sobie światów, próbuję wskazać samą istotę przyjaźni.

W rozdziale trzecim, etycznym, staram się z kolei pokazać, jakie konkretne wnioski dla życia wyprowadziła Teresa z odkrytej przez siebie istoty przyjaźni i w jaki sposób uczyła jej innych. Konfrontuję jednocześnie jej idee z myślą Arystotelesa, wyrażoną w jego Etykach.

W rozdziale czwartym, hermeneutycznym, wykorzystując konkretne sugestie św. Teresy, wskazuję na rolę języka w porozumieniu międzyludzkim, a więc również w tworzeniu związków przyjaźni. Jeszcze raz pomocą służy nam Platon.

Por. A. SCOLA, G. Reale, Il valore dell'uomo, Milano 2007, s. 11-15.

Teresa OD JeZusa, Dzieła, t. I-III, Kraków 1987. Stosuję następujące skróty: Księga życia-Z;

Droga doskonatości-D; Twierdza wewnętrzna-T. 
Zakrojona w ten sposób praca, ze względu na objętość, zostanie podzielona na dwie części. Pierwsza część, rozdziały $1-2$, jest zamieszczona w obecnym numerze „Itinera Spiritualia”. Druga zaś, rozdziały 3-4, znajdzie się w numerze przyszłorocznym.

\section{PrzyjaźŃ i filozofia pRzyjaźni w DZiejaCH}

Trzy wielkie epoki przykuwają moją uwagę w związku z tematem przyjaźni: (1.1) nowożytność (ze współczesnością), (1.2) starożytność (ze średniowieczem) i (1.3) renesans. Ta kolejność, jak się okaże, nie jest przypadkowa. Moim celem nie jest szczegółowa i chronologiczna analiza kwestii przyjaźni w dziejach cywilizacji zachodniej, lecz krytyczne skonfrontowanie ze sobą wybranych epok, wydobycie na światło dzienne ich najbardziej charakterystycznych postaw wobec tego zagadnienia i jednocześnie ujawnienie - cały czas w historycznej perspektywie - naszych współczesnych problemów z przyjaźnią. Na tym tle (1.4) wskazuję na postać św. Teresy od Jezusa, która, chociaż nie była filozofem profesjonalnym, może być naszym przewodnikiem w dialogu z największymi mistrzami filozofii zachodniej, Platonem i Arystotelesem, i w odzyskiwaniu razem z nimi kategorii przyjaźni dla naszych czasów.

Ta krótka wędrówka przez dzieje powinna nam posłużyć w dalszej refleksji, zmierzającej do odkrycia metafizycznego i doświadczalnego sensu przyjaźni (rozdziały 2,3 i 4 ).

\subsection{Przyjaźń i filozofia przyjaźni dzisiaj: zarysowanie problemu}

Przyjaźń w naszych czasach na ogół nie cieszy się wielkim prestiżem i nie wzbudza powszechnego zachwytu. Jest raczej traktowana z przymrużeniem oka, by nie powiedzieć - banalizowana. W każdym razie nie ma dobrej prasy. Szacunek społeczny względem niej też bywa bardzo chwiejny. Nawet w środowiskach tradycyjnie uważanych za kuźnie prawdziwych przyjaźni, na przykład we wspólnotach zakonnych, wyobrażenie o niej znacznie zbladło i w sumie nie wiadomo, jak dzisiaj na serio zabrać się za ten temat. Jej promocji i rozwojowi na pewno nie sprzyja współczesny klimat kulturowy wraz z zimnym społeczeństwem liberalnym, silnie zindywidualizowanym, interesownie nastawionym na ekonomiczny zysk, generującym konkurencję i sprzyjającym dążeniu do władzy i hedonistycznego użycia. Przyjaźń została zepchnięta do sfery prywatnej i stała się synonimem miłości sentymentalnej, uczuciowej, bez większego znaczenia politycznego. Przestała być stylem życia. Według wielu, należy ona wyłącznie do doświadczeń wieku młodzieńczego, później musi ustąpić dojrzałości i samowystarczalności. Brakuje wielkich i żywych wzorców przyjaźni. Samo sło- 
wo stało się bardzo dwuznaczne: wywołuje jeszcze naturalne uczucie radości, entuzjazm i wielkie nadzieje, ale coraz częściej przywołuje też pamięć zranienia, budzi dużą nieufność, powątpiewanie albo wręcz całkowity sceptycyzm. Miłością natomiast, która dzisiaj cieszy się dużym powszechnym uznaniem, jest eros, głośno opiewany i mocno promowany przez mass media, choć bynajmniej nie w formach czystych i wysublimowanych.

W tej sytuacji przeciętny człowiek, mający wyższe aspiracje, w naturalny sposób kieruje swój wzrok ku filozofiom profesjonalnym i w pierwszej kolejności od nich oczekuje pomocy; ich dziejową misją jest przecież udzielanie wsparcia zdrowemu rozsądkowi i myśleniu potocznemu. Oczekuje pomocy, lecz niestety jej nie znajduje. Więlkszość bowiem współczesnych nurtów filozoficznych przestała interesować się tematem przyjaźni i właściwie już go w ogóle nie podejmuje, a przynajmniej nie stanowi on dla nich zagadnienia wiodącego, centralnego, wokół którego krążyłyby wszystkie inne kwestie etyczne, jak to było na przy$\mathrm{k} ł a d \mathrm{u}$ Arystotelesa. Jest co najwyżej jednym $z$ wielu zagadnień, ale na pewno nie ich specjalnością i oczkiem w głowie, gwarantującym wysokiej jakości refleksję etyczną.

Nic więc dziwnego, że Alasdair MacIntyre, katolicki filozof szkockiego pochodzenia, w dziele z 1981 roku Dziedzictwo cnoty. Studium z teorii moralnoścí przeprowadza ostrą krytykę nowożytnej i współczesnej filozofii, twierdząc, że chybiła ona zarówno w swoich badaniach, jak i diagnozach, a ostatecznie zawiodła najgłębsze oczekiwania współczesności. MacIntyre ma na celowniku konkretnie dwie największe nowożytne tradycje filozoficzne, które wypracowały szereg teorii moralnych, często wchodzących ze sobą w konflikt i wzajemnie się znoszacych ${ }^{7}$.

Pierwsza $z$ nich to tradycja oświeceniowa, nazwana przez niego umownie Encyklopedią. Jej głównym reprezentantem jest Immanuel Kant (1724-1804). Moralność próbował on uzasadnić wyłącznie w oparciu o racje czysto rozumowe, odrywając ją od klasycznego pojęcia szczęścia i zakorzenienia w Bogu. W swoim traktacie o cnotach, zatytułowanym Metafizyczne podstawy nauki o cnocie, zagadnieniu przyjaźni poświęca zaledwie cztery strony, i to w końcowej

6 A. Mac'Intyre, After Virtue. A Study in Moral Theory, Notre Dame (In. USA) 1984², ttum. polskie: Dziedzictwo cnoty. Studium z teorii moralności, Warszawa 1996.

7 Błędem obu tradycji było to, że pozostały zbytnio zamknięte w ramach własnych założeń i własnego sposobu myślenia, bez wytworzenia racjonalnych podstaw, umożliwiających prowadzenie twórczego dialogu z innymi filozoficznymi założeniami i typami myślenia; ich dociekania zadowalały jedynie zwolenników własnej tradycji, ale debaty podejmowane z innymi okazywały się niekonkluzywne i kończyły fiaskiem. Por. T. BIESAGA, Alasdair'a Macintyre'a krytka etyki nowożytnej i wspótczesnej, „Analecta Cracoviensia” 28(1996) s. 3-14; tenże, Niepowodzenia nowożytnego i wspótczesnego projektu etyki, w: Spór o etykę. (Materiały z X Jagiellonskiego Sympozjum Etycznego), red. J. Pawica, Kraków 1999, s. 133-142. 
jego części. Przy czym stosunek Kanta do przyjaźni jest dość sceptyczny. Pisze on: „Przyjaźń jest tylko ideą (chociaż ideą praktycznie konieczną), która co prawda w praktyce jest nieosiaggalna, ale dążenie do której (jako do maksimum dobrego usposobienia w stosunku do siebie nawzajem) jest obowiązkiem podyktowanym przez rozum"s.

Drugą z krytykowanych przez MacIntyre'a tradycji jest, zrodzona z reakcji na poprzednią, filozofia życia, którą z kolei określa jako Genealogię. Jej reprezentantem jest Fryderyk Nietzsche (1844-1900). Moralność sprowadził on do woli, a dokładniej do woli mocy, w oparciu o którą zamierzał zrealizować absurdalną i niebezpieczną ideę nadczłowieka. Najbardziej podstawowym błędem tej tradycji jest emotywizm 9 . Błąd ten rozpowszechnił się nie tylko jako teoria, lecz także jako praktyka rozstrzygania sporów moralnych, a nawet pewna mentalność, tak że dzisiaj można już mówić o osobowości i kulturze emotywistycznej ${ }^{10}$. Ponieważ emotywizm wywiera decydujący wpływ na współczesne rozumienie i przeżywanie przyjaźni, trzeba zwrócić nań szczególną uwagę.

Zalążków emotywizmu można się dopatrzeć już w filozofii Davida Hume’a (1711-1776), który stawia rozum i namiętności w ostrej opozycji i dochodzi do stwierdzenia, że moralność jest dziełem namiętności, a nie rozumu ${ }^{11}$. Nie jest na przykład możliwe stwierdzenie: „To jest dobre”, lecz co najwyżej: „To mi się podoba”, „Jestem za tym. Hurra!”. Emotywizm nie zostawia miejsca dla prawdziwie ludzkiego dialogu; zostawia natomiast dużo przestrzeni dla czynników irracjonalnych i manipulacji drugim człowiekiem. Najwięlksze dobra, jakie według tej teorii możemy sobie wyobrazić, to, ni mniej, ni więcej, „uczucia wobec osób i estetyczne przyjemności" - jak pisał George Edward Moore w swym epokowym dziele poświęconym właśnie fundamentom etycznym: Principia Ethica ${ }^{12}$. Sam zaś Nietzsche, sprowadzając sądy moralne dotyczące tego, co dobre i sprawiedliwe, do instynktów, impulsów i doznań, a więc w sumie do sfery biologicznej i psychicznej, twierdził, że wyrażają one ostatecznie i jedynie witalne interesy jednostki lub grup społecznych. Są wyrazem dominujących sentymentów i niewolniczych resentymentów ${ }^{13}$. Zaproponowana przez Nietzschego, a później Freuda psychologiczna interpretacja źródeł moralności i norm etycznych nie daje jednak podstaw do zbudowania ani teorii, ani praktyki autentycznie bezinteresownej przyjaźni. Rodzi się zatem pytanie: gdzie ich należy szukać?

\footnotetext{
I. Kant, Metafizyczne podstawy nauki o cnocie, Kęty 2004, s. 149.

Por. A. Mac'InTYre, Dziedzictwo cnoty, rozdz. II-III, VII i IX.

Por tamże, s. $58 \mathrm{nn}$.

11 Por tamże, s. 105-106.

12 G.E. Moor e, Principia Ethica, Cambridge 1903, rozdz. 6, § 113: „(..) that personal affections and aesthetic enjoyments include all the greatest, and by far the greatest, good we can imagine".

13 Por. F. Niftzsche, Z genealogii moralności. Pismo polemiczne, Kraków 2006, I, § 7 i 10.
} 


\subsection{Przyjaźń i filozofia przyjaźni w starożytności: szukanie źródeł i inspiracji}

Alasdair MacIntyre nie poprzestaje na krytyce nowożytnej i współczesnej filozofii moralnej, z powodu której w trzęsawisku emocji, a może jeszcze bardziej w ciemnościach ślepej i arbitralnej woli ${ }^{14}$, ugrzęzła również kwestia przyjaźni. Proponuje on konkretną drogę wyjścia i stąpanie po pewniejszym gruncie. Wskazuje mianowicie na istnienie, obok oświeceniowej Encyllopedii i nietzscheańskiej Genealogii, jeszcze trzeciej tradycji, konkurencyjnej dla tamtych, i nazywa ją po prostu Tradycją. Chodzi mu o tradycję arystotelesowsko-augustyńsko-tomistyczną, którą uznaje za wyższą nad dwiema pozostałymi ${ }^{15}$. Według niego, sprawdziła się ona przez wieki i jest w stanie zaoferować przekonującą wizję moralności również współczesnemu człowiekowi. Trzeba zatem, mówi, wrócić do źródeł tej tradycji, czyli konkretnie do klasycznego pojęcia natury celowościowej (telos) i do idei jedności cnót ${ }^{16}$.

Chcąc podjać to wielkie i dalekosiężne wyzwanie, warto sobie wcześniej uświadomić, że w greckiej polis, ukierunkowanej kontemplacyjnie i religijnie (w przeciwieństwie do naszej zsekularyzowanej epoki), przyjaźń zajmowała naprawdę centralne miejsce. Stanowiła wręcz spoiwo wszystkich cnót i całego życia duchowego. Miała nie tylko potężny wpływ na życie indywidualne i rodzinne, lecz pełniła również doniosłą funkcję polityczną i społeczną. Była po prostu wzorcem wszelkich międzyludzkich relacji. Zakres znaczeniowy greckiego słowa philia był znacznie szerszy aniżeli współczesnych jego odpowiedników, choćby właśnie polskiego „przyjaźń”. Ci, którzy o niej mówili, starannie odróż-

14 Emotywizm opiera ostatecznie całą moralność na radyk a ln y m w y bor ze, który sam siebie uzasadnia, bez konieczności szukania jakiegokolwiek racjonalnego uzasadnienia. Dlatego Nietzsche zastępuje rozum wolą i deklaruje: „,My jednak bądźmy tym, czym jesteśmy - nowymi, jednok rotnymi, nieporównalnymi, prawodawcami sobie samym, twórcami samych siebie" (Wiedza radosna, Warszawa 1910-1911, s. 274).

15 Por. A. MacIntyre, Three Rival Versions of Moral Enquiry. Encyclopedia, Genealogy, and Tradition, Notre Dame 1990. Jeden z centralnych rozdziałów Dziedzictwa cnoty, IX, zatytułowany jest znamiennie: Nietzsche czy Arystoteles? MacIntyre stawia zatem problem w sposób radykalny: jako alternatywę.

16 Przez powrót do natury celowościowej rozumie on ponowne uznanie, że c z lo w i e k z natury swojej jest ukierunkowany na dobro. Natomiastkonkretnedążenie do tego dobra trzeba oprzeć na trójczłonowym schemacie wypracowanym przez Tr a d y c je: 1) najpierw trzeba zobaczyć naturę ludzką faktycznie daną, jaką ona jest, następnie 2) jaką może się stać, gdy zrealizuje swój cel, i w końcu 3) „umożliwić ludziom zrozumienie, w jaki sposób mogą oni dokonać przejścia z pierwszego stanu do drugiego" (A. MaC'InTYRe, Dziedzictwo cnoty, s. 111; por. S. GatKowsKI, Cnoty irelatywizm. Alasdaira MacIntyre'a próba przekroczenia relatywizmu, "Diametros” 2[2004], s. 11-12; S. WARZESZAK, Znaczenie propozycji filozoficznych Alaisdair MacIntyre'a dla odnowy teologii moralnej, "Warszawskie Studia Teologiczne” 2[2005], s. 253-254). 
niali ją nie tylko od miłości w znaczeniu erosa ${ }^{17}$, lecz także od uczuć i namiętności, których bynajmniej nie przekreślali. Poeci szeroko ją opiewali, filozofowie natomiast dbali o jej czystość. Wszyscy dostrzegali jej znaczenie duchowe i stawiali ją bardzo wysoko w hierarchii cnót.

Arystoteles, przykładowo, ulokował przyjaźn w samym centrum swojej wizji moralności, poświęcając jej w Etyce Nikomachejskiej całe dwie księgi (VIII i IX). Dla porównania warto zauważyć, że cnocie sprawiedliwość poświęcił tylko jedną księgę (V). Ważniejsze jest jednak to, że chociaż tę drugą uważał za cnotę wybitnie relacyjną i nazywał ją wręcz "cnotą doskonałą", „godną pochwały” i „największą z cnót”, to jednak wyżej od niej stawiał przyjaźń. W tejże Etyce napisał: „Ludziom, którzy żyją w przyjaźni, nie trzeba wcale sprawiedliwości, ludzie natomiast, którzy są sprawiedliwi, potrzebują mimo to jeszcze przyjaźni”. I zaraz dodawał: „Najwłaściwszą formą sprawiedliwości jest, jak się zdaje, ustosunkowanie się przyjazne"18. W Etyce Eudemejskiej natomiast wyraził myśl, która ludziom żyjącym w dzisiejszych społeczeństwach wydaje się niemal dziecinnie naiwna: „Zadaniem działalności państwowej jest krzewienie przyjaźni. (...) Jeśliby ktoś chciał sprawić, aby ludzie nie popełniali czynów niesprawiedliwych, wystarczy zrobić z nich przyjaciół, ponieważ prawdziwi przyjaciele nie postępują niesprawiedliwie" 19 .

Jeśli nie chcemy, aby postulat MacIntyre'a powrotu do źródeł Tradycji pozostał w sferze pobożnych życzeń, koniecznie musimy podjąć wysiłki dotarcia do tego celu. Pozostaje tylko pytanie: w jaki sposób dzisiaj możemy to uczynić? Zadanie wcale nie jest proste. Nie wolno nam przecież zmącić jej zasobów, których wartość doskonale wyczuwamy. $Z$ drugiej zaś strony, rzecz nie polega na tym, żeby trzymać się na dystans i jedynie czegoś się o niej dowiadywać. My naprawdę, po przyjacielsku, chcemy zaczerpnąć z jej mądrości, która jest nam bardzo potrzebna do odbudowania pojęcia przyjaźni w odmienionym współczesnym świecie.

Wydaje mi się, że pomocą w tym dziele powrotu do źródeł może służyć praca protestanckiego myśliciela Hansa-Georga Gadamera (zm. 2002), jednego z czołowych przedstawicieli hermeneutyki filozoficznej. Widząc aktualność myśli greckiej, już na samym początku swej filozoficznej drogi wytycza sobie, a jakby

17 Giovanni Reale, pisząc o Platonie, tak ujmuje tę kwestię: „Na ogót platońskie rozważania na temat przyjaźni ( philia) i miłości (eros) rozpatruje się łącznie, ale jest to błędne, bo chociaż mają

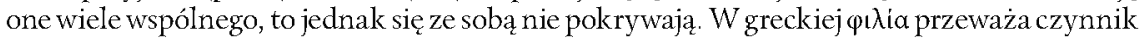
racjonalny albo przynajmniej jest nieobecna owa namiętność i owo »boskie szaleństwo«, które jest szczególną cechą erosa. Dlatego to Platon rozpatruje je odrębnie, przyjaźnią ( philia) zajmując się w Lizysie, a miłością w Uczcie i po trosze także w Faidrosie" (G. Reale, Historia filozofii starożytnej, t. II, Lublin 2005, s. 258).

18 Arystoteles, Etyka Nikomachejska, VIII, 1155 a 27. Cytaty z dzieł Arystotelesa za: tenze, Dzieła wszystkie, t. I-VI, Warszawa 1990-2003

19 Tenże, Etyka Eudemejska VII, 1234 b 32nn. 
wbrew większej części protestanckiej tradycji, pozytywny program: „filozofować z Platonem, nie krytykować Platona: to jest zadanie"20.

Gadamer ma jednak świadomość, że nasza sytuacja jest nieco ambiwalentna: głos Greków daje się słyszeć w taki sposób, jakbyśmy słyszeli samych siebie, ale jednocześnie dochodzi do nas jakby z drugiego brzegu, na który nie możemy już wrócić ${ }^{21}$. Zwykła historyczna reko nstrukcj a tradycji, na zasadzie archeologii czy muzealnictwa, jak to proponowało oświecenie, nie ma wielkiego sensu; tradycja nie jest przecież „przedmiotem”, nad którym należałoby zapanować. I odwrotnie, niewystarczająca jest również romantyczna, zaczerpnięta z nauk przyrodniczych metoda psychologicznego wczuwania się w intencje dawnego autora i zatapianie się w jego duchowe przeżycia; nie chodzi wszakże o zrozumienie samej tylko jego mowy, samego tekstu (sola Scriptura), lecz o „wejście w proces przekazu tradycji, w którym przeszłość i teraźniejszość są stale zapośredniczane" ${ }^{22}$, zbliżenie się w ten sposób do prawdy i zrozumienie samej badanej rzeczy, a więc i po-rozumienie dzisiaj w jej sprawie.

Spontanicznie i naturalnie Gadamer kieruje swoją uwagę na platońską di alektykę i dialog. Za ich pomoca, w oparciu o sokratejską metodę zadawania pytań i szukania odpowiedzi, stara się nawiązać żywą relację z żywą tradycją. W dialogicznym odniesieniu Ja do Ty upatruje on podstaw fenomenu hermeneutycznego. Prosty model rozmowy między dwiema osobami stanowi dla niego wzorzec nowej hermeneutyki: „rozmowa z drugim oznacza wyjście poza siebie, myślenie razem $z$ innymi i powrót do siebie jako do już innego" ${ }^{23}$. Hermeneutyka w takim ujęciu nie jest zwykłą teorią na temat interpretacji i rozumienia źródłowych tekstów, lecz rzeczywistym z nimi di a log i em. Zaczyna się od rzeczy najważniejszej i najtrudniejszej - od zadania im pytania. Niestety, „pomimo Platona jesteśmy na nie [pytanie] bardzo słabo przygotowani”, twierdzi Gadamer ${ }^{24}$.

Z drugiej jednak strony, mamy współcześnie dość dużą świadomość historyczną. Zdajemy sobie sprawę, że kontakt $z$ wszelką tradycją nawiązujemy nie bezpośrednio, lecz zawsze za pomocą tradycji pośrednich, które w międzyczasie naznaczyły nas swoim jej rozumieniem, jakoś ubogaciły, ale i uwarunkowały. Nigdy nie jesteśmy wobec tradycji tabula rasa, jak to naiwnie wyobrażało sobie

20 Cyt za: C. Danani, Lamicizia degli antichi. Gadamer in dialogo con Platone e Aristotele, Milano 2003, s. 23 (tłum. własne)

21 Por. H.G. GaDAmer, Sulla preistoria della metafisica, w: tenże, Studi Platonici, t. II, Genova 1998, s. 3

22 Tenże, Prawda i metoda. Zarys hermeneutyki filozoficznej, Warszawa 2007, s. 400.

23 Tenże, Distruzione e decostruzione, w: Verità e metodo, t. II, Milano 1995, s. 331 (tłum. własne)

24 Tenże, Prawda i metoda, s. 503 (wtrącenie w nawiasie kwadratowym pochodzi od autora). 
oświecenie. Zawsze mamy jakieś przesądy i uprzedzenia, które naznaczają nasze rozumienie rzeczy ${ }^{25}$.

Jedną z owych tradycji pośrednich jest tradycja renesansowa, którą zaprezentujemy głównie w wydaniu św. Teresy od Jezusa. Również ona stanowi pomost łączący refleksję odległych od siebie epok i odznacza się własnym rozumieniem przyjaźni. Pokorne włączenie się w dialog z tą tradycją, i pomiędzy różnymi tradycjami, pozwoli nam pełniej uczestniczyć w prawdzie i razem szukać mądrości, której tak bardzo pragnęli starożytni.

Nie zapominajmy, że najbardziej fundamentalną formą przyjaźni, uosobioną właśnie przez filozofa, jest przyjaźń z mądrością. Filozof wszakże nie jest mędrcem (mądrym jest tylko Bóg! - mówili już starożytni Grecy). Filozof jest przyjacielem mądrości (philo-sophos). I jednocześnie pozostaje w relacji przyjaźni ( philia) do wszystkich innych jej przyjaciół.

\subsection{Przyjaźń i filozofia przyjaźni w renesansie: w obszarze wątpliwości}

Renesans, choć jest najkrótszą z przywołanych tu epok cywilizacji europejskiej, zasługuje na osobną uwagę. Wybrałem ją z dwóch dość partykularnych racji. Po pierwsze, jako ostatnia przed naszymi czasami jest zafascynowana klasycznymi źródłami i ideałami starożytności; wydaje się więc, że w naszym dia$\operatorname{logu} z$ tradycją może mieć wiele do powiedzenia na temat ideału przyjaźni i stanowić dobry pomost w odzyskaniu go dla teraźniejszości. Po drugie, jest to czas, w którym żyje św. Teresa od Jezusa, powszechnie znana jako „przyjaciółka wielu przyjaciół"; z przyjaźni uczyniła ona zasadę swego życia i fundament założonych przez siebie wspólnot; jej konkretne świadectwo może stanowić dobry przykład wcielenia ideału przyjaźni we własne życie.

Trzeba jednak powiedzieć, że w obrębie naszego tematu, dotyczącego filozofii przyjaźni, obie te racje budzą sporo wątpliwości. Spróbujmy je tu zidentyfikować.

Sam okres renesansu zawsze był wielkim utrapieniem dla historyków filozofii. Nie wiedzieli, jak i gdzie w ramach przyjętych kategorii go zaklasyfikować. Stąd zazwyczaj włączali go w ciąg zanikającego już średniowiecza lub w ramy wypowiadającej zaledwie pierwsze słowa nowożytności. Zawieszony między pełnią średniowiecza a pełnią nowożytności był „epoką niezdecydowania” - według dosadnego określenia hiszpańskiego myśliciela José Ortegi y Gasseta ${ }^{26}-$

25 Por tamże, s. 367-399.

26 Cyt. za: R. FLóRes, De la razón renacentista: Esoterismo, la primera Philosophia perennis y El Escorial, w: Tellamar 2, Ávila 2000, s. 62. 
epoką, która „powstrzymywała się od rozwiązywania problemów” - jak z kolei scharakteryzował ją polski filozof Władysław Tatarkiewicz ${ }^{27}$.

Prawdopodobnie właśnie ten niezdecydowany czy wstrzemięźliwy charakter renesansu sprawił, że również jego myśl była pozbawiona precyzji i rygoru, sprzeczna i niekonsekwentna. W rzeczywistości myśl renesansowa - na tle generalnie niezwykłej żywotności tej epoki, upojenia nowymi rodzajami wiedzy, wielkich odkryć geograficznych i astronomicznych oraz niebywałych pomysłów artystycznych $w$ architelturze, malarstwie, rzeźbie i innych dziedzinach sztuki - niestety nie potrafiła wypracować żadnego własnego, oryginalnego konceptu filozoficznego. Odrodzenie wydało naukowców, odkrywców, artystów tej miary co Kopernik, Kolumb, Michał Anioł, a nie wydało żadnego równego im klasą filozofa. Najbardziej znanego spośród nich, Erazma z Rotterdamu, nie można przecież nazwać filozofem. Zdaje się, że „filozofia renesansu jest swego rodzaju no man's land w historii myśli. Filozofia starożytna, filozofia średniowieczna i począwszy od Kartezjusza filozofia nowożytna wznoszą się niczym wielkie pomniki w krajobrazie wyraźnie rozpoznawalnych konfiguracji. Czym jednak jest filozofia renesansu?" - retorycznie zapytuje francuska badaczka renesansu Frances A. Yates ${ }^{28}$. Paul Oskar Kristeller zaś, kolejny wybitny znawca tego okresu, twierdzi jednoznacznie, że wielcy humaniści tej epoki, szczególnie włoscy, "po prostu nie byli filozofami" 29 . Poprzez tłumaczenia greckich tekstów Platona i Arystotelesa na język łaciński przybliżyli oni na nowo kulturze europejskiej myśl klasyczną, stając się jej wielkimi orędownikami i propagatorami, ale sami byli raczej filologami i retorami aniżeli filozofami. Rodzi się więc pytanie: czy mogą oni mieć coś istotnego do powiedzenia w kwestii filozofii przyjaźni?

Fakt, że chętnie sięgali do antyku i przywracali świadomości powszechnej jego wielki dorobek ideowy, nie oznacza jeszcze, że realizowali go we własnym życiu. Widzimy ich bowiem raczej w postawach polemicznych, a nie przyjacielskich i życzliwych. Widzimy, przykładowo, że zrywali z przeszłością bezpośrednio minioną i, z pewnymi wyjątkami, negowali wielki dorobek scholastyki. Owszem, początkowo, w XV wieku, przez udzielenie we Włoszech gościny uczonym bizantyńskim, recepcję ich greckiej filozofii oraz założenie we Florencji Akademii Platońskiej na wzór tej, która istniała w Atenach (Kosma Medyceusz, Marsilio Ficino, Pico della Mirandola), byli wielkimi rzecznikami myśli rekoncyliacyjnej: dążyli do pojednania nie tylko Platona z Arystotelesem i Platona z chrześcijaństwem, ale również przywrócenia utraconej jedności pomiędzy chrześcijańskim Wschodem i Zachodem (Sobór Florencki, 1439_ -1443). Z czasem jednak, w XVI wieku, stali się otwartymi rzecznikami

27 W. Tatarkiewicz, Historia filozofii, t. II, Warszawa, s. 3.

28 F.A. Yates, Ensayos reunidos, t. II, México 1991, s. 140 (tłum. własne).

29 P.O. Kristeller, El pensamiento renacentista y sus fuentes, Madrid 1993, s. 124. 
myśli antagonistycznej, konfrontacyjnej: zradykalizowali zrodzone z reakcji na średniowiecze postawy antropocentryzmu, antydogmatyzmu i antyracjonalizmu; podważyli wielką zachodnią tradycję „platonizmu chrześcijańskiego” i wczesnorenesansową koncepcję philosophia perennis; zaczęli głosić hasła wolnościowe i przyjmować w dyskusji polemiczny ton; weszli w konflikt z przyjętymi poglądami Kościoła, państwa i opinii powszechnej; stali się w końcu jedną z głównych sił, które doprowadziły do nowego rozbicia w Kościele zachodnim (Luter, Erazm ${ }^{30}$. Czy można zatem widzieć w nich dobrych świadków przyjaźni?

Nie mniej wątpliwości budzi zwrócenie się w tej pracy, poświęconej filozofii przyjaźni, ku postaci św. Teresy od Jezusa. Już na pierwszy rzut oka - jeśli tylko weźmiemy pod uwagę współczesne poglądy na temat tego, czym jest filozofia - rodzi się podejrzenie o megalomanię lub błąd metodologiczny. Wygląda to, jakbyśmy „prostej kobiecinie”, za jaką się uważała, kazali mówić pojęciami abstrakcyjnymi. Wiadomo przecież, że Teresa nie była filozofem $z$ wylsształcenia. Nie studiowała na żadnym uniwersytecie. Nigdy nie czytała pism Platona, Arystotelesa ani żadnego innego filozofa starożytności z wyjątkiem św. Augustyna, nie mówiąc o naukowych opracowaniach z filozofii. Samo zagadnienie przyjaźni w twórczości Teresy powraca co prawda nieustannie, ale w szeregu jej pism nie stanowi przecież jakiegoś odrębnego i metodologicznie usystematyzowanego traktatu; nie pretenduje ona nawet do pisania tego rodzaju rozpraw. Zresztą, samo życie zakonne, tak specyficzne w jej przypadku, nie pozwalało jej na zajmowanie się zagadnieniami filozoficznymi w sposób naukowy.

Jeśli poszerzymy nasz horyzont i popatrzymy na jej twórczość od strony literackiej, ściśle związanej z zagadnieniami filozoficznymi, to zauważymy, że od pewnego momentu - mniej więcej od pięćdziesiątego roku życia - bardzo dużo pisze: ma pragnienie i potrzebę pisania. I czyni to z entuzjazmem, pasja, prawie bez umiaru, nawet gdy zapewnia czytelnika, iż bierze pióro do ręki wyłącznie z posłuszeństwa. Intencje jednak, z jakimi się podejmuje tego dzieła, są bardzo znamienne: „prócz spełnienia obowiązku posłuszeństwa, innego w tym pisaniu swoim zamiaru nie mam, jedynie pragnę pociągnąć (engolosinar) dusze do tak wysokiego dobra" (Ż 18, 8). Teresa mówi dosłownie, że chce czytelnika zwabić, ujać, uwieść, pozyskać, skłonić, przekonać, rozpalić. Raz po raz nawetjak zauważa jeden ze współczesnych badaczy strategii retorycznych używanych przez Świętą z Awili w jej mistycznym języku - „puszcza oko”31 do czytelnika. Widząc to wszystko, skłonni jesteśmy myśleć, że Teresa uprawia raczej (dobrą) retorykę aniżeli filozofię, próbuje oddziaływać na sferę emocjonalną, a nie na

30 W. Tatarkiewicz, Historia filozofii, s. 5-8.

31 J.A. MARCos, Mística subversiva: Teresa de Jesís. Las estrategias retóricas del discurso místico, Madrid 2001, s. 13 
myśl. Przez swoje dzieło literackie zdaje się w każdym razie wpisywać doskonale w ogólne renesansowe tendencje, na które już wcześniej zwróciliśmy uwagę.

Ponadto ma tę osobistą i osobliwą „wadę”, która zdaje się potwierdzać nasze przypuszczenia: w swoim pisaniu ulega spontaniczności i daje się ponieść bujnej fantazji i uczuciom. Powszechnie znane sa jej ciaggle dygresje i nawroty do tematów raz podjętych, a nigdy niezakończonych; jej „nieporządek” w tym zakresie stanowi dla niektórych tak wielką przeszkodę, iż uniemożliwia im lekturę jej pism. Niewiele zmienia tu fakt, że Teresa nie rozpoczyna pisania, nie mając jasnej intencji i ściśle określonego celu. Ostatecznie bowiem w jej przypadku górę zawsze bierze praktyczne przeznaczenie nad intelektualną ścisłością, doświadczenie mistyczne nad spekulacją. W duchu renesansowego antropocentryzmu i charakterystycznego dla tej epoki indywidualistycznego niepokoju lubuje się w mówieniu o swoich osobistych, subiektywnych doświadczeniach, co oczywiście zbliża ją do nowożytności, ale stwarza też wielkie niebezpieczeństwo zagubienia, albo przynajmniej zdewaluowania prawd odwiecznych i niezmiennych. Tak czy owak, cała ta jej żywiołowość wydaje się stanowić kolejny argument przemawiający przeciw filozoficzności jej wypowiedzi i w ogóle zdolności do powiedzenia jakiegoś znaczącego słowa na temat przyjaźni dla naszych pełnych zamętu czasów.

\section{4. Św. Teresa od Jezusa „filozofem przyjaźni”?}

Wydaje się, że są jednak argumenty, które przemawiają na korzyść Teresy. W moim przekonaniu jest ich więcej i są mocniejsze od przytoczonych wyżej argumentów przeciwnych. Czasami są ukryte i nie rzucają się od razu w oczy. Zadaniem poniższego studium będzie odsłonięcie ich współczesnemu czytelnikowi. Jest to zadanie bardzo pilne. Chodzi mianowicie o pokazanie, że Teresa przekazuje dzisiejszemu człowiekowi cały szereg stale obowiązujących prawd o przyjaźni, a nie jedynie psychiczne czy emocjonalne przeżycia; i że w jej pismach jest obecna autentyczna filozofia przyjaźni, a nie tylko retoryka mająca na celu pozyskanie sobie czytelnika ${ }^{32}$.

\subsubsection{Cechy filozofii terezjanskiej}

Filozofia Teresy nie ma oczywiście rodowodu akademickiego i obca jest jej naukowość w dzisiejszym tego słowa znaczeniu; nie jest formą zeświecczonej, wąsko rozumianej wiedzy, autonomicznie opartej na samym rozumie (ratio)

32 Nie dewaluujemy tu bynajmniej świata psychicznych czy emocjonalnych przeżyć ani roli retoryki w życiu idziele Teresy; tematy te zostaną szeroko omówione odpowiednio w rozdziałach 3 i 4 ninicjszej pracy. W tym jednak miejscu, chcąc pozostać wiernym myśli i nauczaniu Teresy, nie można nie podkreślić ich wtórnej pozycji w stosunku do prawdy filozoficznej. 
i na dodatek rozdzielającej logos i ergon, palabra i obra. Doskonale natomiast wpisuje się w klasyczną wizję filozofii, której początek dali Platon i Arystoteles: obejmuje całość rzeczywistości, także jej wymiar duchowy i religijny; jest uczestnictwem w prawdzie, „chodzeniem w prawdzie”; jest wręcz upodobnieniem się do Boga.

„Jakżebym chciała porozmawiać z dobrym filozofem!" (D 19, 3) - wykrzyknęła kiedyś z głębi swego jestestwa i w jednej chwili dała wyraz przynajmniej trzem rzeczom. Najpierw, w dobie wspomnianego już kryzysu filozofii, wyraziła rozczarowanie $z$ powodu braku dobrych filozofów w swojej epoce; jakby chciała zapytać: gdzież oni są?, gdzież się podziali?, gdzie renesans w filozofii? Następnie, wysoko ceniąc należyte rozumienie rzeczy, wyraziła swój wielki szacunek dla samej filozofii i tęsknotę za ludźmi świattymi, za letrados, których rady zawsze szukała i teraz też jej potrzebuje ${ }^{33}$. W końcu i przede wszystkim, czując się związana z prawdą, przez ów okrzyk wyraziła własną najbardziej fundamentalną postawę filozoficzną, a mianowicie poczucie poznawczej bezradności, owo słynne sokratejskie „wiem, że nic nie wiem”, a jednocześnie namiętne pragnienie mądrości ${ }^{34}$. Ta postawa zasadniczej nie-wiedzy i szukania z pasją mądrości, bez której nie ma żadnej dobrej filozofii, będzie Teresie towarzyszyć stale: będzie budzić w niej filozoficzne zdziwienie; będzie inspiracją do zadawania autentycznie filozoficznych pytań; będzie w końcu źródłem niespożytych sił do wprowadzania innych w prawdziwie mądrościową filozofię.

Jest jeszcze jeden rys jej filozofii, który zbliża ją do filozofii klasycznej, a jednocześnie wynosi ją i różni od niej o całe niebo. Jest nim klucz hermeneutyczny. Otóż, jeżeli kluczem hermeneutycznym do filozoficznych dialogów Platona jest figura Sokratesa, filozofa, który nie stoi z boku wydarzeń, ale angażuje się i ponosi śmierć dla prawdy (logos), to kluczem hermeneutycznym do filozoficznego wymiaru pism i samego życia Teresy jest postać Jezusa Chrystusa, Filozofa, który sam będąc Najwyższą Prawdą, przez swoją śmierć odsłania Prawdę ostateczną, osobową. Filozofia, każda filozofia, jest w istocie stosunkiem do tej właśnie Prawdy (Logos) $)^{35}$.

33 Por. T. Alvarez, Filosofia, w: Diccionario de Santa Teresa. Doctrina e Historia, Burgos 2002, s. 306-307.

34 Platon przedstawił Sokratesa jako wcielenie filozofa, jako człowieka, który nie chce być mędrcem, lecz raczej tym, który z namiętnością (erosem) poszukuje mądrości. Por. m.in Uczta, 204 A. Dzieła Platona w języku polskim cytuję za: Dialogi, t. I-II, Kęty 1999; Państwo, Prawa (VII Ksiag), Kęty 1999.

35 W szóstym mieszkaniu Twierdzy wewnętrznej Teresa stawia na jednej płaszczyźnie poganina Piłata i nas, chrześcijan, pisząc: „Przychodzi mi tu na myśl Piłat, który z takim lekceważeniem traktował rzecz tak wielką, gdy Panu w czasie Męki Jego tak mimochodem i z pogardą zadał pytanie: cóż to jest prawda? Ale jak ten ślepy poganin, tak podobno i my wszyscy, póki żyjemy na ziemi, mało co wiemy o tej Prawdzie Najwyższej" (T VI 10, 5) 
Filozofia Teresy - jak zobaczymy w konkrecie - odznacza się metafizyczną głębią i wielką dojrzałością myśli, jest wnikliwa i konsekwentna. Potrafi wyjść poza pospolite mniemania i szukać samej istoty przyjaźni. Nie traci przy tym związku z doświadczeniem. Umie precyzyjnie odróżnić prawdziwą i zdrową przyjaźń od fałszywej i chorej. Niesie ze sobą ogromny potencjał relacyjny, który uzdalnia ją nie tylko do tworzenia dojrzałych i trwałych wspólnot przyjaźni, lecz także do prowadzenia intelektualnego i duchowego dialogu $z$ innymi filozofiami.

\subsubsection{Rodowód kategorii "przyjaźni"}

Mistyczka hiszpańska, rozmyślając nad sobą i nad swymi relacjami z ludźmi i z Bogiem, w sposób całkowicie naturalny sięga po kategorię przyjaźni. Spodziewa się, że obejmie nią wszystkie dotychczasowe, niezwylle żywe doświadczenia swego życia. Prawdopodobnie jednak nie zdaje sobie sprawy, że jest to kategoria z gruntu filozoficzna i ma swój „naukowy” rodowód w filozoficznie nastawionej Grecji, a nie w żydowskiej Biblii, w której - trzeba to podkreślić - nie odgrywa jakiejś kluczowej roli ${ }^{36}$. Biblia, owszem, mówi o przyjaźni Jonatana z Dawidem, ale ten świetlany przykład nie znajduje na jej dalszych stronach odpowiedników - jak na przykład kategoria „brata”, która, począwszy od Kaina i Abla, powraca na kartach Pisma Świętego nieustannie i odsłania coraz to głębsze teologiczne znaczenia. W Księgach mądrościowych, przenikniętych kulturą grecką, nie brakuje wzniosłych myśli na temat przyjaźni, ale i one nie zostają znaczeniowo rozwinięte i nie są wpisane w samą istotę starotestamentowego przesłania. W Nowym Testamencie Jezus gości u swoich przyjaciół w Betanii (por. Łk 10, $38-42 ; \mathrm{J} 11,1-44 ; 12,1-11$ ), a moc modlitwy ukazana jest w przypowieści o natrętnym przyjacielu (por. Łk 11, 5-8), jednak i tutaj określenie „przyjaciel” nie ma wyraźnego przełożenia na obecną w nim teologię (dokładniej, chrystologię). Cała teologiczna moc, głębia i doniosłość tego słowa wybrzmiewają dopiero wtedy, gdy Jezus wszystko już wyjawi uczniom, odsłoni przed nimi ich przeznaczenie i całym sobą da im wzór postępowania ${ }^{37}$. Dodajmy, że pierwsi chrześcijanie,

36 Dla całego akapitu por. C. De Villapadierna, Amigos de Jesús, w: Diccionario de Jesús, red F.F. Ramos, Burgos 2007, s. 54-56; E.M. Nieto, Amistad, w: Diccionario de Jesús, s. 56; J.T. Lienhard, Amistad. Amigos, w: Diccionario de San Agustin. San Agustin a través del tiempo, red. A.D. Fitzgerald, Burgos 2001, s. 37-39.

37 „Nikt nie ma większej miłości od tej, gdy ktoś życie swoje oddaje za przyjaciół swoich. Wy jesteście przyjaciółmi moimi, jeżeli czynicie to, co wam przykazuję. Już was nie nazywam sługami, bo sługa nie wie, co czyni pan jego, ale nazwałem was przyjaciółmi, albowiem oznajmiłem wam wszystko, co usłyszałem od Ojca mego. Nie wyście mnie wybrali, ale Ja was wybrałem" (J 15, 13-16; por. teżŁk 12,4n.). Ten niezwykle ważny tekst umieszczam w przypisie wyłącznie ze względu na przejrzystość wywodu. Znajdzie on jednak swój f i l o z o f i c z n y wyraz w konkluzji naszej pracy. 
w wierności biblijnemu nauczaniu, też nie skupiali się na przyjaźni. Nazywali się po prostu „braćmi”, a nie „przyjaciółmi”.

Teresa natomiast, pomimo że płynęła w niej krew żydowska i pomimo że słowo Boże stanowiło dla niej najwyższą normę postępowania i kształtowało jej ducha, nie ma najmniejszych oporów, by sięgnąć po kategorię z filozofii greckiej i uczynić z niej - jak już powiedzieliśmy - zasadę swego życia i fundament założonych przez siebie wspólnot. Kategorię tę $w$ pewnym momencie wyniesie oczywiście na poziom teologiczny, gdzie w wewnętrznym dialogu ze Słowem objawionym, w którym wszystko zostało stworzone (por. Kol 1, 16), odsłoni ona swój specyficznie chrześcijański charakter, ale nigdy nie dopuści, aby zagubiła ona swoją filozoficzną naturę. Zgodnie z najlepszą tradycją, również w jej przypadku łaska nie niszczy, lecz zakłada i doskonali naturę (gratia non destruit sed supponit et perficit naturam).

\subsubsection{Renesansowy kontekst kulturowy i jego echa dziś}

$\mathrm{Na}$ koniec tych historycznych wywodów warto zauważyć, że spontaniczne „wyjście" Teresy poza literę Biblii i jej odwołanie się do filozoficznej kategorii "przyjaźni”, należącej de facto do tradycji greckiej, a nie stricte biblijnej, dokonuje się w dobie luterańskiego skupienia się na samym tylko Piśmie Świętym (sola Scriptura), radykalnego „czyszczenia” Biblii i chrześcijaństwa z wszelkich wątków helleńskich (dehellenizacja), uznania ratio za prostytutkę babilońską, odrzucenia „dzieła” ludzkiego (ergon, obra) w relacji z Bogiem jako demonicznego i ostatecznie zerwania eklezjalnej jedności. Chrześcijańska dojrzałość Teresy jest jak widać tak wielka, że nie potrzebuje usuwania elementów greckich, by dowartościować własne.

Filozoficzna postawa w wyborze kategorii przyjaźni nie zasługiwałaby na szczególną uwagę i można by ją nawet odesłać do historycznego lamusa, gdyby nie fakt, że na początku XX wieku teolog luterański Adolf von Harnack ponownie wysunął postulat o „hellenizacji dogmatów chrześcijańskich”. Stał się on zasadą interpretacji całego rozwoju doktryny chrześcijańskiej. Zasugerował Kościołowi zachodniemu coś, co właśnie od czasów renesansu wraca falami, a mianowicie, że czystość i uniwersalizm chrześcijaństwa domagają się jego "dehellenizacji”, to znaczy porzucenia schematów pojęciowych i pryncypiów filozoficznych, jakie teologia chrześcijańska pierwszych wieków wypracowała w spotkaniu z filozofią grecką, szczególnie pod wpływem platonizmu. Jak wiadomo, debata na temat "prawomocności” spotkania między chrześcijaństwem a kultura grecką w pierwszych wiekach trwa do chwili obecnej. Nie brak i takich, także po stronie katolickiej, którzy idąc w ślady Lutra, w dalszym ciągu 
obarczają ojców Kościoła pierwszych wieków „winą” za to spotkanie i rzekome zamazanie czystości przesłania chrześcijańskiego ${ }^{38}$.

Ukazanie kontekstu wyboru kategorii „przyjaźni” przez Teresę nie ma, jak widać, charakteru wyłącznie historycznego i nie ogranicza się do jakiejś wąskiej perspektywy. Jesteśmy wciagnięci w nurt kwestii aktualnych, a niezwykle głębokich, delikatnych i ważnych dla wszystkich wierzących w Chrystusa. Są to kwestie na styku filozofii i teologii, kwestie, które pokazują, iż obie tradycje, biblijna i filozoficzna, są ściśle ze sobą powiązane, wciąż żywe i od dwudziestu wieków mają sobie coś do powiedzenia.

\subsubsection{Dwie metodologiczne trudności i próba uporania się z nimi}

Napotykamy tu jednak dwie konkretne trudności. Pierwsza dotyczy pisma, druga tradycji. O pierwszej była już częściowo mowa w punkcie 1.3. Przypomnijmy więc krótko, że Teresa nie zostawiła po sobie żadnego systematycznego traktatu na temat przyjaźni, na wzór traktatów arystotelesowskich. Jej nauczanie na ten temat trzeba dopiero wydobyć z licznych i rozproszonych fragmentów jej stosunkowo obszernego dzieła literackiego; trzeba je, warstwa po warstwie, cierpliwie układać w pewną logiczną i spójną całość. Teresa nie pisze w sposób uporządkowany; nie pisze „z głowy”, ale całą sobą, tak jak czuje i przeżywa w danej chwili; zgodnie ze swoim żywym temperamentem. Wielu, dając się uwieść jej wielkiemu urokowi, zatrzymuje się na poziomie jej niepowtarzalnej osobowości i nie dochodzi do odczytania jej rzeczywistej myśli, która - podkreślmy jeszcze raz - jest czymś więcej niż tylko ekspresją uczuć i magią słów.

Nie chcę oczywiście wyolbrzymiać tej trudności. Teresa sama nie byłaby $z$ tego zadowolona i z pewnością mocno by zaprotestowała. Dwie swoje księgi pisała przecież w optyce przyjaźni. W swojej autobiografii (Księga życia) zostawiła nam tchnące autentyzmem opisy stanów swojej duszy, w których wprost mówi o osobistych doświadczeniach przyjaźni z ludźmi i z Bogiem. W Drodze doskonatości natomiast, która stanowi rodzaj podręcznika nowego stylu życia dla ufundowanych przez nią wspólnot, podejmuje się roli nauczycielki przyjaźni. Oba te pisma są rodzajem dialogu, jaki prowadzi z całym szeregiem osób, przede wszystkim ze swoimi siostrami z klasztoru. Swoim bezpośrednim stylem zbliżają się one bardziej do dialogów platońskich aniżeli do arystotelesowskich traktatów. Droga doskonatości jednak ma coś z arystotelesowskiego Protrepty$k u$, w którym, jak zresztą we wszystkich platońskich dialogach, wyrażona jest

38 Por. E. Peroli, Ontologia della finitezza. Sul rapporto tra platonismo e cristianesimo, w: Seconda navigazione. Omaggio a Giovanni Reale, red. R. Radice, G. Tiengo, Milano 2015, s. 535-572, zwł. s. 541. 
zachęta do podjęcia życia na sposób filozoficzny. W naszych analizach skupimy się głównie na tych dwóch pismach, choć nie wyłącznie.

Gdy chodzi o drugą trudność, związaną z tradycją, trzeba stwierdzić, że wpływ kultury renesansowej na egzystencjalne wybory św. Teresy niestety nie został do tej pory dostatecznie zbadany. Nie wiemy dokładnie, na ile ówczesna epoka wyraziła się $w$ doświadczeniu Teresy i na ile Teresa zrealizowała renesansowy program powrotu do klasycznych źródeł moralnych. Jeden z bardziej wnikliwych badaczy jej życia i doktryny zauważa:

W mówieniu o św. Teresie mało się podkreśla jej powiązania z mentalnością humanizmu i renesansu. Owszem, wspomina się o „humanizmie” terezjańskim, opartym na jej głęboko ludzkim sposobie bycia i działania, umiejętności łagodnego i roztropnego korzystania z środków ascetycznych, ale bez żadnego powiązania z kulturą. A tymczasem jest ona kobietą odznaczającą się kulturą znacznie wyższą od średniej epoki ${ }^{39}$.

W niniejszej pracy nie stawiam sobie za cel nadrobienia owych braków. Przebadanie powiązań zachodzących pomiędzy katolicką kulturą XVI-wiecznej Hiszpanii, w tym osobistą kulturą Teresy, a renesansową fascynacją kulturą grecką i jej moralnymi źródłami przekracza moje skromne możliwości naukowe, jak i zakres tej pracy. Chcę natomiast zdecydowanie wyjść poza rozpowszechnione dzisiaj, ciasne ujęcia przyjaźni terezjańskiej, które ograniczają ją do aspektów wyłącznie afektywnych; w moim przekonaniu nie oddają one sprawiedliwości jej wizji, chociaż są miłe dla ucha współczesnego człowieka. Chcę stanąć oko w oko $z$ wielką filozoficzną tradycją i jej mądrościowym wymiarem, który - obejmując również afektywność - jako jedyny jest w stanie otworzyć człowieka na głębszą tajemnicę (teologia) i przez to rzeczywiście zasługuje na miano prawdziwego humanizmu.

\section{Od wielu Przyjaciół do Pierwszego Przyjaciela}

W tej części artykułu oddajemy się pod przewodnictwo dwóch wielkich mistrzów „życia filozoficznego”, życia zgodnego z rozumem: Platona i św. Teresy od Jezusa. Nie jest przypadkiem, że im właśnie powierzamy przewodnictwo w naszej wędrówce: są oni również mistykami i swoim spojrzeniem sięgają dalej niż najwięksi nawet filozofowie. Podzielą się też własnym rozumieniem przyjaźni. Platon uczyni to na drodze spekulacji, która przybierze u niego formę

39 D. de Pablo Maroto, Teresa en oración. Historia. Experiencia. Doctrina, Madrid 2004, s. 95 (tłum. własne). 
dialogu, Teresa natomiast - poprzez wyznanie własnych doświadczeń, które $z$ kolei przybiorą literacką formę opowieści (ale też i dialogu). Jednak nie styl wypowiedzi jest tu najważniejszy, lecz zdolność położenia me ta fi z y c z n y ch podstaw przyjaźni oraz naświetlenia jej wartości i istoty. Długa droga, jaką oboje przebyli od „wielu” przyjaciół do „Jednego” Przyjaciela, i ich pragnienie upodobnienia się do Niego odsłaniają przed nami ostateczny fundament etyki przyjaźni, o której będziemy mówili w rozdziale trzecim, gdzie z kolei św. Teresa pojawi się w towarzystwie Arystotelesa. Jednakże uprzednie wskazanie na metafizyczny fundament przyjaźni jest pewnym sygnałem, że jest nam potrzebny powrót od Arystotelesa do Platona ${ }^{40}$.

Zobaczymy w zarysie najpierw platońską „ideę” przyjaźni, a następnie terezjański „dar” przyjaźni - ich podobieństwa, różnice i ponadczasowe znaczenie obu tych wizji.

\subsection{Platońska „idea” przyjaźni}

Jaką ideę przyjaźni miał Platon? Nim spróbujemy odpowiedzieć na to pytanie, musimy uświadomić sobie jedną niebagatelną rzecz, a mianowicie - że jest ono sformułowane... w języku współczesnym! (I oczywiście, nie mogło być sformułowane inaczej). Żeby jednak uchwycić, co ten fakt naprawdę oznacza, musimy zauważyć, że centralne słowo tego pytania - idea - ma w nim znaczenie zupełnie odmienne od znaczenia, jakie w starożytności nadawał mu Platon (odmienne tym samym od słowa „idea” z powyższego tytułu). Uświadomienie sobie tej różnicy jest ważne dla zrozumienia naszych dalszych wywodów.

\subsubsection{Platońska koncepcja „idei”}

Współcześnie przez słowo „idea” rozumiemy wytwór naszego umysłu, wyobrażenie czegoś jako myśl, pojęcie, a więc coś, co zostało przez człowieka wykreowane na płaszczyźnie psychologicznej i ma wartość wyłącznie subiektywną, taką, jaką mu nadaje dany człowiek. Platon natomiast - znany wielu współczesnym ze swoich „idei”, ale niestety często pojmowanych właśnie jako subiektywne kreacje, a więc błędnie - rozumie przez nią coś o b i e k tywnego, jakiś przedmiot, jakiś realny byt, na którym myśl może się zawsze zatrzymać, skupić i autentycznie zaistnieć. Zdolnośc do uchwycenia „idei” stanowi poniekąd o godności ludzkiej myśli.

"Idea”, według Platona, jest więc bytem prawdziwie istniejącym, stanowiącym podstawę dla wyróżnienia dalszych „idei”, w tym także „idei” przyjaźni. Jest ona „wzorcem”, „paradygmatem” i „modelem”, służącym dla modelowania wszystkich rzeczy zmysłowo postrzegalnych, włącznie $z$ własnym życiem. Jest

40 Por. R. Brague, Ancore nel cielo. Linfrastruttura metafisica, Milano 2011, s. 89 (tłum. wlasne) 
to byt niezależny i samoistny; niecielesny wprawdzie, niemniej jednak inteligibilny, czyli możliwy do poznania umysłem, dokładniej - „niepokalanym rozumem" "41, to znaczy umysłem niezależnym od zmysłów. Jest to byt wieczny i niezmienny, niepodlegający wpływom skończonego i niestałego świata, niezależny też od wpływu zmiennych ludzkich namiętności.

Najważniejszą jednak cechą „idei” jest jed no ść. Będąc „jednością”, idea tłumaczy „wielość” rzeczy istniejących, między innymi wielość rzeczy postrzeganych zmysłowo. Rzeczy te istnieją i mają sens o tyle, o ile uczestniczą w owej idei. W przeciwnym wypadku ulegają rozproszeniu i zaginięciu. $Z$ wielości istniejących rzeczy tworzy ona jedność.

Ponadto cała rzeczywistość, każdy byt, każda istniejąca rzecz, poczynając właśnie od samej „idei”, ma tę dwubiegunową strukturę: Jedno-Wielość. Struktura ta, według Platona, została przekazana starożytnym w jakimś „boskim objawieniu", a więc nie jest tworem człowieka, lecz czymś, co otrzymał on w darze. W dialogu Fileb Platon tak mówi o pochodzeniu prawdy, dotyczącej wewnętrznej struktury rzeczywistości:

Bogowie dali ją ludziom; tak mi się to przedstawia (...). I starożytni oni lepsi byli od nas i bliżej bogów mieszkali - to nam podanie przekazali, że wszystko, co, jak się mówi, istnieje, składa się z jedności pewnej i z wielości, i ma w sobie przyrodzony pierwiastek granicy i nieokreślenia ${ }^{42}$.

Nie tylko jednak istniejące byty, a więc wymiar ontologiczny, charakteryzują się tą strukturą - również cała gnozeologia, czyli teoria i metoda poznania tych bytów, ludzka myśl i dialektyka. Toteż platońska dialektyka realizuje swój poznawczy cel na dwa sposoby: najpierw w postępowaniu synoptycznym (wstępującym), przechodząc od wielości do jedności, a następnie w postępowaniu diairetycznym (zstępującym), w którym przebiega drogę w przeciwnym kierunku. Innymi słowy, prowadzi do zrozumienia tej „zadziwiającej” rzeczy, o której mówi Fileb, mianowicie do uchwycenia, w jaki sposób „w i ele jest jed ny m i jedno jest wielo ma”. W najwyższym stopniu wiedzę tę ma tylko boski Rozum: „tylko sam Bóg wie dobrze, jak mieszać w jedn ą całość różne [wiele] elementy i potem je rozłączać [czyli z jedności prowadzić do wielości]”"33.

Wbrew powszechnym mniemaniom, platońska „idea” jest czymś niezwykle konkretnym i może być wręcz „widziana”. Dzięki owej bipolarnej strukturze

41 Platon, Fedon, 65 C-66 A.

42 Tenże, Fileb, 16C.

43 Tenże, Timajos, 68 D. Wtrącenia w nawiasach kwadratowych są własnymi wyjaśnieniami tekstu. Por. G. Reale, Historia..., s. 203. 
jest ona bowiem również „formą”, „kształtem” albo „postacią” każdej rzeczy - jest jej istotą. Ponieważ jednak jest to „forma” wewn nętrzna, nie może być oczywiście widziana oczyma ciała, ale nie mniej realnie może być widziana „oczyma umysłu”, „oczyma duszy”. Dodajmy, że oba te wyrażenia są również dziełem Platona i stanowią kolejną cząstkę jego wielkiego wkładu w kulturę europejską. Co prawda, w dzisiejszej zmysłowej i materialistycznej kulturze te „oczy” bardzo osłabły, niedowidzą już rzeczywistości duchowej, a nawet wydają się zupełnie niepotrzebne w realiach codziennej pragmatyki, jednak nie zapominajmy, że jeszcze cztery wieki temu tymi właśnie „oczyma duszy”, „oczyma umysłu" św. Teresa zobaczyła swego Jedynego Przyjaciela, który w sposób decydujący zaważył na kształcie jej dalszego życia. Są to „oczy” typowe dla duchowej kultury Greków, która jest przede wszystkim kulturą „widzenia”, kulturą „formy”, kultura „,kształtu”. Trafnie zauważa Friedländer:

Platon miał [...] plastyczne oko Hellena, oko równe co do natury temu, którym Poliklet dostrzegał kanon [...]; i tej samej natury co oko, które grecki matematyk kierował ku czystym formom geometrycznym. Platon był chyba świadomy tego daru, który pośród wszystkich myślicieli jemu najbardziej przypadł w udziale $[\ldots]^{44}$.

Miał on jednak również świadomość (wielki realista!), że teoria „idei” może natrafić na wielkie trudności w przyjęciu ze strony wielu ludzi, szczególnie ludzi powierzchownych, sprowadzających poznawanie do sfery wyłącznie zmysłowej, zewnętrznej. Wielu z nich może powiedzieć, że skoro nie widzą „idei” oczyma ciała, to znaczy, że one po prostu 1) nie istnieją, 2) nie są możliwe do zrozumienia, a zatem 3) nie jest też możliwe przekazanie ich innym (nauczenie ich). Tę swoją obawę/wątpliwość Platon włożył w usta Parmenidesa, jednego $z$ uczestników dialogu zatytułowanego tym imieniem:

Trzeba doprawdy być nie byle kim, żeby móc zrozumieć, że 1) is t n ieje pewien rodzaj [forma, postać, kształt] każdego przedmiotu oraz jego is tota sama w sobie. A jeszcze większego podziwu godzien byłby ktoś, kto by to i 2) zna leźć [czyli: zrozumieć] potrafił, i 3) umiał kogoś drugiego o tym na u c zyć, przemyślawszy to wszystko aż do końca. - Zgadzam się z tobą, Parmenidesie - powiedział Sokrates. - Bardzo mi to po myśli, co mówisz $z^{45}$.

44 Cyt. za: G. Reale, Historia..., s. 90; nawiasy kwadratowe w dziele G. Realego; całość wywodu na temat „idei” por. tenże, s. 88-112.

45 Platon, Parmenides, 135 A-B. 
Teresa, jak zobaczymy, każdy z tych trzech punktów powtórzy i odniesie do tajemnicy „daru”.

Niezależnie od trudności, na jakie może natrafić również wśród nas platońska teoria „idei”, zechciejmy sobie uświadomić, że cała europejska myśl, jej kultura, wszystkie jej instytucje są naznaczone tą platońską strukturą „idei”: „wielość-w-jedności - jedność-w-wielości”. Znajduje ona swój prozaiczny wyraz także w bipolarnej strukturze naszej pracy. Rozdział drugi, niniejszy, zatytułowany jest Od wielu przyjaciót do Pierwszego Przyjaciela. Rozdział trzeci natomiast będzie nosił tytuł Od Pierwszego Przyjaciela do wielu przyjaciót.

Spróbujmy tu przynajmniej wymienić niektóre z platońskich idei. Są nimi „formy” inteligibilne, możliwe - jak powiedzieliśmy - do ujęcia „oczyma duszy”, „oczyma umysłu”, takie jak wieczne istoty dobra, prawdy, pięlnna, sprawiedliwości, męstwa albo - interesująca nas tu szczególnie - wieczna istota przyjaźni.

\subsubsection{Platońska koncepcja „przyjaźni”}

Platon daje pierwszy wielki szkic idei przyjaźni w swoim dialogu Lizys. Pamiętajmy, że jest to jeden z wcześniejszych jego dialogów, należący do grupy tzw. dialogów sokratejskich, w których nie miał jeszcze dopracowanej do końca swojej teorii „idei”. Jak zwykle jednak, zaczyna od rzeczy zewnętrznych, bardzo zmysłowych. W sposób niezwykle plastyczny kreśli najpierw świąteczną atmosferę w ateńskiej palestrze, w której urodziwi i inteligentni chłopcy rozmawiają $z$ Sokratesem właśnie na interesujący nas temat. W pewnym momencie jednak Platon stawia zasadniczy problem. Czyni to za pomoca postaci Sokratesa, który w rozmowie $z$ młodzieżą ateńską otwiera serce, solidarnie wyjawia swoje pragnienia i pokazuje, że są one bardzo podobne do tych, jakie i oni noszą we własnych sercach. Co więcej, zazdrości im nawet - co wyraża nie bez sporej dawki ironii - czegoś, co oni już posiedli, a on jeszcze nie, pomimo że w swoim życiu przebył już długą drogę. Oto jego słowa:

Bo ja już od chłopięcych lat - jakoś tak mi padło - pragnę posiąść pewien skarb; jak to jeden pragnie tego, drugi czego innego. Jeden chciałby mieć konie, inny psy, inny złoto, a ktoś inny zaszczyty. Ja się tam do takich rzeczy nie palę, ale żeby przyjaciół zyskiwać - do tego mnie żądza gna. Znaleźć dobrego przyjaciela - ja bym wolał to, niż posiąść najlepszą w świecie przepiórkę albo koguta - ba, na Zeusa - ja bym to wolał niż konia i psa! Zdaje mi się, na psa, że raczej niż posiąść skarby Dariusza, wolałbym znaleźć przyjaciela. Nawet to o wiele prędzej niż samego Dariusza! Tak mi jakoś potrzeba przyjaźni. Więc kiedy tak na was patrzę, na ciebie i na Lizysa, to szeroko otwieram oczy i usta, i mówię: oto szczęśliwcy! Że tacyście młodzi, a potra- 
filiście ten skarb znaleźć i prędko, i łatwo; tyś w nim takiego przyjaciela znalazł prędko i tak mocno go posiadasz, a on znowu ciebie. A ja taki jestem daleki od tego skarbu, że nawet tego nie wiem, jak to się jeden staje przyjacielem drugiego ${ }^{46}$.

Zakres dalszej rozmowy daleko wybiega poza współczesne, wąskie rozumienie przyjaźni jako związku między dwiema osobami. Oprócz tego obejmuje szereg tematów bardzo technicznych i specjalistycznych. W naszej refleksji pominiemy kwestie drugorzędne, a skupimy się tylko na jednej, istotnej, która wyraźnie charakteryzuje całą platońską wizję i ma ponadczasowe znaczenie. Jednocześnie dziwnie koresponduje z wizją terezjańską. Ponadto wydaje się ona tak fundamentalna, że nie może jej pominąc ktoś, kto ma na uwadze współczesną konieczność odbudowania idei przyjaźni.

Giovanni Reale tę platońską ideę/wizję przyjaźni zreasumował krótko:

Według Platona przyjaźń zawiązuje się nie tylko w kierunku (...) czysto horyzontalnym, lecz także wznosi się w kierunku wertykalnym, to znaczy transcendentnym. To, czego szukamy w ludzkich przyjaźniach, zawsze odsyła jeszcze do czegoś innego i każda przyjaźń nabiera sensu jedyn ie ze względu na „Pierwszego Przyjaciela” (proton philon) ${ }^{47}$.

Innymi słowy: platońska idea/wizja przyjaźni ma w istocie dwa wymiary: horyzontalny i wertykalny. Pierwszy wymiar to przyjaźnie w liczbie mnogiej, jest ich tu wiele. Są one zawierane między ludźmi i są doświadczane zmysłowo; same w sobie, bez oparcia na innym fundamencie, są zmienne i nietrwałe. Na ich temat istnieją też najróżniejsze mniemania. Drugi zaś wymiar to przyjaźn w liczbie pojedynczej. Chodzi tu o przyjaźn z Pierwszym Przyjacielem (proton phiton). Jest ona odkrywana na drodze inteligibilnej; jest odwieczna i nie podlega żadnej zmianie. Ma wszystkie wcześniej już wspomniane cechy „idei”. Jest przede wszystkim ,jednością” i jako taka jest też determinująca dla „wielu” przyjaźni międzyludzkich. Zbiera je wszystkie, od najmniejszej do największej, w jedno. Bez niej, tzn. bez uczestnictwa w niej, inne przyjaźnie nie mogłyby nawet powstać i w ogóle nie zasługiwałyby na to miano. Byłyby bowiem czystą iluzją. Sam Platon tak o tym mówi (ustami Sokratesa):

Czyż nie musimy utracié tchu po drodze, kiedy się tak będziemy cofali wstecz [od jednej przyjaźni do innej], albo dojść do jakiego początku, który już nas nie odeśle do czegoś innego przyjaznego? To będzie to pierwsze

46 Tenże, Lizys, $211 \mathrm{D}-212 \mathrm{~A}$.

47 G. Reale, Historia..., t. II, s. 259. 
przyjazne [Pierwszy Przyjaciel]; ze względu na nie wszystkie inne rzeczy są i uchodzą u nas za przyjazne. (...) Ja to mówię dlatego, żeby was te wszystkie inne rzeczy, któreśmy nazwali przyjaznymi ze względu na tamto pierwsze, nie wprowadzały w błąd. To są jak gdyby jakieś jego widziadła. A tamto pierwsze i jedynie ono tylko jest tym, co naprawdę przyjazne ${ }^{48}$.

Może się tu jednak rodzić pewna wątpliwość: czy to posuwanie się długą drogą „od przyjaciela do przyjaciela”, aż w nieskończoność, aż do zaparcia tchu, nie prowadzi do przyjaciela, owszem, najwyższego, ale wciąż jeszcze należącego do tej samej hierarchii rodzajowej, a więc przyjaciela w liczbie mnogiej, będącego „jednym z wielu innych przyjaciół”? Naszą wątpliwość rozwiewa Gadamer, wielki znawca filozofii platońskiej, w następujący sposób:

To, co u Platona jawi się jako cel najwyższy, jako pierwsza „miłość”, wzięta w sensie ścisłym, nie jest czymś maksymalnym, albo czymś najwyższym w jakiejś hierarchii, wznoszącej się po tych samych stopniach aż do najwyższych pułapów. Ów „pierwszy” jest, przeciwnie, jedynie platońskim wyrażeniem, które później, w kontekście nauki o ideach, zostanie znacznie bardziej doprecyzowane. To natomiast, co tutaj ma się na uwadze, jest in nym sposobem bycia, a nie wznoszeniem się w ramach tego samego bytu. U podstaw przyjaźni leży więc coś, co jest „d ro g i e” w znaczeniu bardzo odmiennym od tego, co jest mi drogie, gdy mi służy [do jakiegoś dalszego celu $]^{49}$.

Jest to, zdaje się, najgłębszy teoretyczny wniosek, jaki można wyciągnąć z Platońskich spekulacji na temat przyjaźni w Lizysie. Uwzględniając bowiem całą naukę Platona, łączy oba wcześniej wspomniane wymiary: wertykalny $z$ horyzontalnym, ale nie niweczy ich odrębności. I co najważniejsze - wskazuje na metafizyczną podstawę przyjaźni, na „Pierwszego Przyjaciela” (proton philon), mianowicie: na ideę Dobra.

\subsubsection{Metafizyka Dobra}

O idei Dobra Platon nauczał raczej ustnie w swojej Akademii, natomiast na piśmie przedstawił ją po raz pierwszy w centralnej części swojego późniejszego dialogu, jakim jest Państwo (w księdze VI). To jednak, co o idei Dobra napisał, było właściwie - by użyć tu jego własnych słów - jedynie spłaceniem „odsetek”,

48 Platon, Lizys, 219 C-D. Ze względu na zrozumiałość naszego wywodu w miejsce słowa "miłe" zostało wprowadzone słowo „przyjazne”.

49 H.G. GADAmER, Logos e ergon nel Liside di Platone, w: tenże, Studi Platonici, s. 69 (podkreślenia i tłum. własne). 
a nie wyrównaniem całego długu, który trzeba spłacić gdzie indziej (poza pismem). Dobro, w ujęciu Platona, nie jest bowiem jakimkolwiek dobrem, ale Dobrem w sensie najgłębszym, Dobrem sam ym w sobie, a nie tylko, jak chciał Arystoteles, dobrem dla mnie, dobrem rozumianym pragmatycznie. W tym sensie jest ono niezwykle trudne do poznania i prawie niemoźliwe do wyrażenia, szczególnie pisemnego.

Spłacając owe „odsetki”, Platon pisał właściwie nie wprost o samym Dobru, ale - odwołując się do gry słów w swoim języku - o „synu” wielkiego „ojca” (Dobra); i przedstawił go (syna) w słynnej metaforze słońca, które jest źródłem światła. Promienie słońca rozświetlają każdą rzecz i naszym wzrokiem możemy każdą z osobna widzieć taką, jaka rzeczywiście jest w całej prawdzie; nad to, o ile słońce daje oku odpowiednią zdolność widzenia, o tyle też ono samo może być przez nie oglądane. Analogicznie do tego, co dzieje się w sferze zmysłowej dzięki słońcu - tak samo dzieje się również w sferze inteligibilnej dzięlki Dobru: ono nadaje prawdę poszczególnym rzeczom i samo może być przez nas poznawane. I jak słońce stoi ponad wzrokiem i oglądanym przedmiotem, tak samo Dob ro stoi ponad poznaniem i prawdą.

Musimy jednak zrobić jeszcze jeden krok do ukazania platońskiej idei Dobra jako metafizycznego fundamentu etyki ${ }^{50}$, w tym także etyki przyjaźni, o której będzie mowa w rozdziale trzecim. Otóż słońce nie tylko oświetla rzeczy, dając nam możliwość ich poznania (epistemologia), ale jest również źródłem ich zrodzenia (genesis), zaistnienia, a więc samego życia i jego rozwoju (ontologia). Ten elementarny fakt nie był wystarczająco brany pod uwagę w naukowej filozofii bytu ostatnich wieków, chociaż jest on najbardziej fascynującą prawdą urzekającą każdego niemal człowieka. Urzeczony nią Platon mógł z prostotą i prawie mimochodem powiedzieć: „Przedmiotom poznania nie tylko poznawalność dzięki Dobru przysługuje, ale również is tnienie, oraz is tota ich od niego pochodzi, chociaż Dob ro to nie jest istota, tylko coś pon ad wszelką istotę, coś wyższego i mocniejszego o wiele" 51 . Dzięlki umiejscowieniu Dobra w sferze innej niż w bycie i ponad istotą Platon stworzył nie tylko „metafizykę światła”, ale również „metafizykę życia”. Nie wystarczyły mu bowiem same moralne racje przemawiające na rzecz zachowania życia - potrzebował solidniejszych podstaw, które dostarczyłyby mu głębszych racji dla (od)dania życia i spłacenia tym samym długu wobec Dobra.

50 Ten metafizyczny fundament etyki, jakim jest D o b ro, można nazwać również warunkiem życia moralnego, albo, za E. Levinasem, etyką, jako filozofią pierwszą; por. E. Levinas, Étique comme philosophie première, Paris 1998.

51 Platon, Państwo, 509 B; por. cały passus na temat metafizyki Dobra: 504 A - 509 C; por również G. Reale, Historia..., t. II, s. 131-140. Platońskie założenie etyki na Dobru stanowi podstawową tezę następującego studium: E. LevinAs, Inaczej niż być lub ponad istota, Warszawa 2000 


\subsubsection{Pragnienie Dobra a zaspokajanie własnych potrzeb}

„Pierwszym Przyjacielem, którego rzeczywiście pragniemy i do którego dążymy, ,jest nic innego, jak tylko pierwsze i absolutne Dobro”. „Przyjaźń zaś łącząca jednego człowieka $z$ drugim jest tylko wtedy autentyczna, jeśli jest środkiem dojścia do Dobra"52, a dokładniej-jeśli jest wyrazem pragnienia Dobra. Całą bowiem sprężyną przyjaźni nie jest jakaś potrzeba, lecz właśnie pragnienie. Gdyby była nią potrzeba, wówczas dążyłoby się do jakiegoś dobra mocą zła, wyrażającego się w braku; z chwilą zaś ustąpienia owego zła znikłaby również potrzeba dobra. To z kolei mogłoby oznaczać, że rzeczy „drogie” - przyjaciele - mogą zaistnieć tylko w doświadczaniu zła ${ }^{53}$.

Chcąc rozwiać i tę wątpliwość, Gadamer pyta, czy wszellie pragnienie ma rzeczywiście tego rodzaju naturę, że zależy od potrzeby, od tego, czego komuś brakuje, tak że to, do czego się dąży, przestawałoby być dobrem z chwilą zaspokojenia potrzeby. W odpowiedzi jednak podkreśla, że ustąpienie braku bynajmniej nie zakłada zniknięcia pragnienia tego, co jest rzeczywiście drogie i przyjazne. Nie można więc powiedzieć, że pragnienie, jakie pociąga i jednoczy przyjaciół, polega na tym, że jeden dla drugiego jest tym, co tamtemu brakuje, a więc jest przyjacielem dopóty, dopóki trwa ów brak. Prawdziwa przyjaźń między istotami ludzkimi nie polega na sprowadzeniu wszystkiego do chęci zapomnienia w niej o sobie i własnych potrzebach; polega raczej na tym, że jeden dla drugiego staje się ciągle czymś więcej; jeden w drugim znajduje własną coraz głębszą samoświadomość.

Jeśli coś jest „drog i e” samo w sobie, a nie z uwagi na coś innego, to oznacza, że rzeczywiście istnieje coś, co jest drogie niezależnie od faktu, że ten, kto doświadcza owego pragnienia, postrzega siebie w stanie negatywnym i próbuje zaradzić temu stanowi. Trzeba zatem starannie rozróżnić dwa zupełnie odmienne znaczenia przymiotnika „drogi”: pierwsze „korzystny” i drugie „rzeczywiście" (to onti) drogi ${ }^{54}$.

\subsection{Terezjański „dar” przyjaźni}

Słowo „dar” z tytułu niniejszego podrozdziału użyte jest w analogii do „idei” przyjaźni z tytułu podrozdziału poprzedniego. Tego rodzaju zestawienie platońskiej „idei” i terezjańskiego „daru” zmierza do pokazania podstawowych zbieżności, jakie zachodzą między tymi pojęciami (2.2.1), a jednocześnie stawia sobie za cel ułatwienie prześledzenia „długiej drogi”, jaka prowadziła Teresę

52 G. Reale, Historia..., t. II, s. 259

53 Por. Platon, Lizys, $221 \mathrm{C}-\mathrm{D}$.

54 Por. H.G. GaDAMER, Logos..., s. 70. 
do spotkania Pierwszego Przyjaciela (2.2.2.) i kontemplacji istoty przyjaźni (2.2.3).

\subsubsection{Filozofia platońska $w$ terezjańskiej koncepcji przyjaźni}

Filozofia platońska, której kilka charakterystycznych elementów wyżej naszkicowałem, stanowi prawdopodobnie najgłębsze racjonalne podłoże terezjańskiej koncepcji przyjaźni. Nie ma potrzeby wykazywania tutaj wszystkich zależności myśli Teresy od tej filozofii. Niektóre z powiązań mają jednak szczególne znaczenie i koniecznie trzeba je wydobyć. Myśl terezjańska o przyjaźni ukazuje bowiem swoje pierwotne subtelności dopiero dzięki zestawieniu jej z oryginalnym światłem filozofii platońskiej.

Istnieją oczywiście również ogromne różnice między platońską „ideą” a terezjańskim „darem” przyjaźni. Wynikają one przede wszystkim z odmiennych koncepcji Boga i odmiennych teologii. Platon nie dysponuje tak potężnym źródłem poznawczym jak św. Teresa, czyli biblijnym objawieniem. Nie zna on Boga chrześcijan i nigdzie nie mówi o osobowej relacji przyjaźni z pojętym osobowo Bogiem. Jest wciąż uwikłany w greckie wierzenia religijne, w których to, co boskie, pozostaje zawsze bardzo dwuznaczne. Jeżeli nawet w jego teologicznej wizji występuje Bóg osobowy, Demiurg, to jednak stoi on niżej w hierarchii niż na przykład idee, które owszem, mają boski charakter, ale to nie on je stwarza, lecz jest od nich zależny. Platon nie zna Boga miłości, miłosierdzia, przebaczenia, który objawił się w Jezusie Chrystusie. Nie wie, że obdarowuje On słabego człowieka wielką przyjaźnią i udziela mu łaski, by mógł na tę przyjaźń odpowiedzieć całym sobą.

Wyraźne i nieusuwalne rozbieżności między Platonem a Teresą na płaszczyźnie teologicznej nie podważają bynajmniej - podkreślmy to jeszcze raz - ich zgodnego przebywania na płaszczyźnie filozoficznej. Teresa - z pewnością nieświadomie, ale de facto - wchodzi w orbitę metafizyki Platona i asymiluje cały szereg wypracowanych przez niego pojęć filozoficznych, które służą jej jako narzędzie poznawcze i komunikacyjne. Nawet w jej język modlitwy, którym wyraża swoją przyjacielską relację z Bogiem, wplecione są liczne zwroty zaczerpnięte $z$ tradycji platońskiej.

Zwróćmy uwagę najpierw na rzecz najbardziej prozaiczną, a jednak fundamentalną: na formę bi er n ą zarówno platońskiej „idei”, jak i terezjańskiego „daru” przyjaźni. Idea, jak mówi grecki mistyk, nie jest wymysłem człowieka, lecz „darem bogów dla ludzi”, który ich determinuje i z nią wiąże; również „dar”, według doświadczeń hiszpańskiej mistyczki, nie jest w pierwszej kolejności czymś, co ona komuś ofiaruje, lecz co sama otrzymała i co ją trzyma; chodzi mianowicie o dar przyjaźni, jaki posiada, albo lepiej-jaki ją posiada. Ten bierny charakter daru przyjaźni nie oznacza bynajmniej bezczynności ze strony 
Teresy. Zobaczymy w następnym podpunkcie, ile wysiłku i zmagań kosztowało ją rozpoznanie i wdzięczne przyjęcie go.

Po wtóre, obie wizje przyjaźni, platońska i terezjańska, zbudowane są w oparciu o to samo dialektyczne napięcie Jedno-wiele, które sprawia, że ich wewnętrzna struktura jest taka sama, to znaczy d w u b i e gu nowa. Teresa jest jej w pełni świadoma i nieprzypadkowo cały materiał dotyczący przyjaźni dzieli na dwie części, idealnie odpowiadające tej strukturze: pierwszą zamieszcza w Księdze życia, druga natomiast w Drodze doskonałości. Przyjrzyjmy się temu dokładniej.

W pierwszych dziesięciu rozdziałach Księgi zycia Teresa opowiada, zgodnie $z$ dialektyką Jedno-wiele, dzieje swojej długiej wędrówki od wielu przyjaciół do Jednego Przyjaciela: to znaczy od chwili pierwszych dziecięcych zwierzeń, przez doświadczenia intensywnych relacji w młodości i dramatyczne zmagania w okresie pierwszych dwudziestu lat życia zakonnego, aż do momentu spotkania Pierwszego Przyjaciela, Jezusa Chrystusa, którego, paradoksalnie, spotyka jako ostatniego. Ciekawa jest rzecza, że wielość zmysłowo przeżywanych w tym czasie przyjaźni (rozdziały 1-10) zostaje przez Teresę zrozumiana i wytłumaczona dopiero w chwili spotkania Jedynego Przyjaciela (rozdziały 11-22 i następne). Można powiedzieć, że cała ta wędrówka jest swoistym s y noptycznym wznoszeniem się ku definitywnemu oświeceniu i przejrzeniu na oczy na szczycie góry. Dopiero stamtąd Teresa może spojrzeć wstecz, popatrzeć na całość swego życia i w świetle Jednego Przyjaciela dostrzec, że wiele z tego, co na każdym etapie uważała za przyjaźń, było tylko cieniem prawdziwej przyjaźni, jej wyobrażeniem, albo nawet w ogóle nie było przyjaźnią (bo ostatecznie nie przetrwało).

Trzeba jednak pamiętać, że Teresa nie opowiada o swoich przyjaźniach „na bieżąco", lecz snuje opowieść z perspelktywy osoby dojrzałej, żyjącej już w wielkiej przyjaźni z Bogiem, mającej nie tylko świadomość otrzymanego „daru”, ale również głębokie zrozumienie jego znaczenia. I chociaż Teresa opowiada o sobie, tak naprawdę chce pouczyć innych. Chce mianowicie na podstawie osobistych doświadczeń wytłumaczyć czytelnikom, że prawdziwa przyjaźń zasadza się nie na uczuciach i wolitywnych wysiłkach, i w ogóle nie jest ludzką własnością, lecz w pierwszej kolejności jest czymś zapożyczonym, otrzymanym, przyjętym z zewnątrz. Trzeba więc najpierw otworzyć się na Pierwszego Przyjaciela, odbyć długą wędrówkę do Niego i przyjąć Jego d a r przyjaźni.

Swoje nauczanie na temat przyjaźni Teresa rozwinie w Drodze doskonatości. Przedstawi w niej, w oparciu o własne doświadczenia zdobyte na szczycie, druga stronę platońskiej dialektyki: Jedno-wiele. Wytłumaczy, jak przechodzić od Jednego Przyjaciela do wielu przyjaciół, to znaczy jak budować trwałe więzi przyjaźni między ludźmi w relacjach horyzontalnych, społecznych, jak wprowadzać jedność do wielości, porządek w miejsce nieporządku. Droga Teresy prowadzi 
teraz z góry w dół po własnych śladach; jest dia i re ty czn y m zs tę powan i em, rozumnym dzieleniem jedności na wielość, ale już ze znawstwem, w poznaniu istoty przyjaźni, jej doskonałej miary i odpowiadających jej form. Teresa, która zobaczyła prawdziwe oblicze i postać Pierwszego Przyjaciela, może jeszcze raz zobaczyć oblicza i postacie poszczególnych przyjaźni, przez które wspinała się ku najwyższemu poznaniu; teraz jednak widzi je takimi, jakie są naprawdę. I to właśnie daje moc jej nauczaniu.

Kolejną, może najbardziej istotną zależność terezjańskiej myśli o przyjaźni od filozofii platońskiej dostrzegamy w ramach epokowego odkrycia, którego Platon dokonał jako pierwszy w dziejach. Chodzi o odkrycie św ia ta pon adzm y słowe go, inteligibilnego ${ }^{55}$, świata, który jest „miejscem” wiecznego trwania zarówno idei, jak i daru. Nie można nie zauważyć, że cała kultura europejska, nolens volens, jest naznaczona tym odkryciem - nawet wówczas, gdy w praktyce je ignoruje, jak to widać na przykładzie płaskiego materializmu, który zaprzecza istnieniu innego świata niż materialny, albo gdy ostentacyjnie je kontestuje, jak to z kolei świadomie czyni pewna część współczesnej kultury antymetafizycznej, która interpretuje i urządza widzialny świat wprost w reakcji na platońskie odkrycie wymiaru niewidzialnego (nolens). Odkryciem tym naznaczona jest oczywiście również Teresa, która - inaczej właśnie niż znaczna część współczesnej kultury - całą duszą je przyjmuje i chętnie z niego korzysta (volens). Widzimy to niemal na każdej stronie jej pism, gdzie wciąż posługuje się platońskim rozróżnieniem na świat zmysłowy i ponadzmysłowy ${ }^{56}$. Na różne

55 Por. Platon, Fedon, 97 C - 102 A. Platon dochodził długo do odkrycia św i a ta pon a d z m y s łow e go. Pozostając najpierw pod wpływem filozofów przyrody, sądzil, że za pomocą ich metod poznawczych, opartych na siłach natury i zmysłach, znajdzie odpowiedź na dręczące go pytania o przyczynę istnienia wszystkich rzeczy. W pewnym momencie jednak uświadomił sobie, że te metody nie są w stanie wyjaśnić całej rzeczywistości. Postrzegane zmysłami rzeczy (kolory, kształty, wszelkie fenomeny) nie uzasadniają istnienia dobra, piękna, przyjaźni czy - jak w przypadku Sokratesa przebywającego w więzieniu - zgody na oddanie swego życia za prawdę. Chcąc przeżyć te ideały, nie wystarczy zatem - by odwołać się tu do pięknego platońskiego obrazu - polegać jedynie na „pierwszym żeglowaniu”, to znaczy żeglowaniu z wykorzystaniem samych podmuchów wiatru, sił natury, zmysłów, namiętności. Trzeba koniecznie sięgnąc do „drugiego żeglowania”, do pracy rąk i wiosel, czyli - na głębszym poziomie - do rozumu. Dopiero na tej inteligibilnejdrodze jesteśmy w stanie odkryć prawdziwą przyczynę istnienia dobra, prawdy, przyjaźni. Por. na ten temat: G. Reale, Historia..., t. II, s. $75-87$

56 Nie ma w tym żadnego dualizmu. Platońskie „idee” i terezjański „dar” są bowiem metafizycznym fundamentem i przyczyną istnienia wszystkich fenomenalnych rzeczy. Ani Platon, ani Teresa nie przeciwstawiają fundamentufenomenom, lecz precyzyjnieje rozróżniają Dualizm pojawia się natomiast na płaszczyźnie antropologicznej, gdy Platon, a za nim Teresa, przeciwstawia duszę ciału. Czasami jest to okrutne względem ciała, ale trzeba przyznać, że w sumie jest to jedynie niewielki wycinek ich etycznego nauczania, który ostatecznie zostaje wchłonięty przez szerszą met a f i z y c $z$ ną perspektywę. Staje się natomiast wielkim problemem, gdy tej zabraknie. Aktualność platonskiego rozróżnienia na świat zmysłowy iświat ponadzmysłowy potwierdził współcześnie Jan Paweł II w swojej filozoficznej encyklice 
sposoby przekonuje czytelnika, że zatrzymanie się w świecie zmysłowym rodzi iluzje i naraża na uwikłanie w wielość zmiennych, kruchych i krępujących emocji, a w konsekwencji nie prowadzi do przeżycia autentycznej przyjaźni; konieczne jest przekroczenie zamkniętego w sobie świata uczuć i otworzenie się na świat nadzmysłowy, inteligibilny, rozumny, świat, który jest „miejscem” zamieszkania Jednego Przyjaciela, umożliwiający prawdziwą wolność ducha.

Ta platońsko-terezjańska optyka przyjaźni, która jest optyką na wskroś met afizy c zną, gdyż korzeni człowieka i fundamentów moralności (przyjaźni) poszukuje w niebie ${ }^{57}$ i rości sobie pretensje do bycia uniwersalną, zawiera w sobie konkretny problem, który w naszych czasach pozostaje wyjątkowo trudny do intelektualnego zgryzienia. Chodzi o stosunek przyjaźni do a fektywności (i odwrotnie). W ostatnich latach wiele napisano na temat uczuć i świata afektywnego św. Teresy. Temat stał się bardzo atrakcyjny i nie należy się dziwić, że poświęca się mu tyle uwagi: rzadko spotykamy w dziejach przykłady tak bogatego i doskonale rozwiniętego świata uczuć, jak właśnie u św. Teresy. Odnosi się jednak nieodparte wrażenie, że część literatury terezjańskiej frywolnie interpretuje jej odniesienie do uczuć w kluczu wyłącznie genetycznym i sentymentalnym. Zauważa się to na przykład w ostrej, naturalistycznej reakcji na dawną hagiografię, która - nie można temu zaprzeczyć - była zbyt spirytualistyczna i niejednokrotnie pomijała rolę emocjonalności w drodze do świętości. Konsekwencją jednak tej gwałtownej reakcji jest dzisiaj jeszcze bardziej radykalna przesada, polegająca na jednostronnym skupieniu się na aspekcie cielesnym, seksualnym i emocjonalnym, z zupełnym pominięciem wymiaru metafizycznego i bladym odniesieniem do wymiaru etycznego. Z lubością natomiast ukazuje się Teresę jako model kobiety, potrafiącej w sposób wolny, to jest bez ograniczeń, represji i zahamowań wyrażać swoje uczucia. Ten ostatni aspekt jest entuzjastycznie akcentowany. Wygląda to tak, jakby ekspresywizm miał być główną cechą życia Teresy (podczas gdy jest główną cechą naszych czasów ${ }^{58}$ ).

Afektywno-ekspresywny as pekt przyjaźni jest niewątpliwie bardzo wyraźny w życiu i nauczaniu Teresy od Jezusa. My zajmiemy się nim osobno w trzecim i czwartym rozdziale naszej pracy, poświęcając mu wystarczająco dużo miejsca. Nie on jednak stanowi główny przedmiot jej troski i dominantę w doświadczeniu przyjaźni. Nie on również jest centralnym problemem tego zagadnienia w naszych czasach. Kwestia uczuć i kwestia ekspresji mają się dzisiaj

Fides et ratio (14 września 1998), w której napisał: „Wielkie wyzwanie, jakie stoi przed nami u kresu obecnego tysiąclecia, wyzwanie równie nieuniknione jak pilne, polega na przejściu od fe nom enu do fund a me n tu" (JAN PaWEe II, Fides et ratio, 83; podkreślenia moje).

57 Por Platon, Timajos, $90 \mathrm{~A}$.

58 Por. Ch. TAYLOR, Źródta podmiotowości. Narodziny tożsamości nowoczesnej, Warszawa 2001, szczególnie część czwarta, zatytułowana Gtos natury, a w niej rozdz. XXI: Zwrot ekspresywistyczny, oraz część piąta, zatytułowana Subtelniejsze języki. 
raczej dobrze, przynajmniej w tym sensie, że istnieje duże nimi zainteresowanie. Problemem natomiast jest brak metafizy ki, brak świadomości i wyczucia potrzeby metafizyki, a ostatecznie - brak odpowiedniej dla potrzeb naszych czasów metafizyki. Nie wchodząc w szczegóły tej niezwylkle złożonej, a ważnej dzisiaj kwestii, jedno jest pewne: Platon i Teresa, rozmyślając o przyjaźni, nie zatrzymują się na tym, co cielesne, zmysłowe, empiryczne, fizyczne; uparcie natomiast poszukuja, w pełnym poszanowaniu całej fenomenalnej rzeczywistości, jej fundamentu niecielesnego, ponadzmysłowego, ponadempirycznego i ponadfizycznego. Są przy tym nie tylko racjonalnymi metafizykami, ale również doświadczonymi mistykami - w swoich poszukiwaniach umieją odwołać się do najgłębszych motywów religijnej wiary.

Zwieńczeniem, szczytem tej metafizyczno-mistycznej perspektywy przyjaźni jest wspólna Platonowi i Teresie idea Dobra. Wprawdzie Platon rozumie Dobro bezosobowo, wyłącznie właśnie jako ideę, a więc odmiennie aniżeli Teresa, jednakże dla obojga właśnie ono stanowi ostateczny, boski fundament przyjaźni. O Dobru u Platona już mówiliśmy. Znamienne jest natomiast, że św. Teresa od Jezusa, chociaż sama nie jest profesjonalnym filozofem, często i chętnie zwraca się do boskiego Przyjaciela językiem, który w swym wydźwięku jest bardziej racjonalny niż sentymentalny: „Dobro”, „Najwyższe Dobro”, „Najwyższe Dobro moje”, „Źródło dobra”: „Wiesz dobrze, o najwyższe Dobro moje, że jeśli jest we mnie co dobrego, nie $z$ innych rąk to otrzymałam, jeno z Twoich" (D 15,5 ; por. $\dot{Z} 4,3 ; 8,6 ; 14,10 ; 17,2 ; 19,6 ; 21,5 ; 22,3 ; 29,12 ; 35,14$; D 19, 9; 22, 6; T VI, 9, 12 i in.). Jednocześnie potrafi dać takie oto praktyczne wskazanie:

Kto prawdziwie miłuje Boga, ten wszystko miłuje, cokolwiek jest dobrego, i cokolwiek jest dobrego, pragnie, i cokolwiek jest dobrego, popiera, i cokolwiek jest dob r e go, pochwala, i z każdym dobrem się łączy, i wszędzie gotów go bronić, i wszelką c not ę sercem obejmuje, i niczego nie kocha, jeno p rawdę i co jest godnym kochania. Czy sądzicie, by ten, kto prawdziwie miłuje Boga, mógł jeszcze kochać się w marnościach ziemskich? (D 40,3).

Ani Platon, ani Teresa nie mają najmniejszych wątpliwości, że prawdziwi miłośnicy boskiego Dobra kontemplują je we wszystkich „dobrach” ziemskich, ale te ostatnie nabierają charakteru względnego i stają się ostatecznie „marnościami”, jeśli nie są ukierunkowane i nie uczestniczą w Dobru najwyższym. Oboje zdają sobie też sprawę, że ich koncepcje przyjaźni, oparte na niebiańskich fundamentach, moga jednak stwarzać ogółowi ludzi niemało trudności. Platon mówił o tym wprost, gdy przedstawiał swoją teorię „idei” (przyjaźni) (por. punkt 2.1.1). Również Teresa, w słowach, które są prawie kopią słów Platona, wyraża własną świadomość tej trudności. Zwracając się do o. Garcii z Toledo, swego 
wielkiego przyjaciela i adresata Księgi życia, a mając na uwadze właśnie „dar przyjaźni" z Bogiem, tak pisze:

1) Otrzymać dar od Pan a to pierwsza laska, 2) a druga jest ta, gdy ten, kto go otrzymał, zrozumie, jaka to ła ska, i jakie jej własności; 3) nakoniec, umieć ten dar słowy wyrazić i wytłumaczyć, na czym się zasadza, to trzecia jeszcze odrębna łaska" (Z 17,5$)$.

Teresa czuje jednak, że otrzymała tę potrójną łaskę (dar). Nie zważając zatem na żadne trudności, postanawia podzielić się nią z innymi. Nie realizuje tego zadania wzorem platońskim, metodą intelektualnych spekulacji, lecz we własnym, kobiecym stylu, opowiadając doświadczenia wyniesione ze swojego życia.

\subsection{2. „Dtuga droga” Teresy do Pierwszego Przyjaciela}

Platon miał świadomość, że ten, kto chce zbliżyć się do poznania samego Dobra, „musi iść d rogą dłuższą naokoło, musi uczyć się i trudzić przy tym nie mniej niż przy ćwiczeniach cielesnych" ${ }^{59}$. Nie inaczej miały się sprawy w życiu Teresy od Jezusa. Przyglądnijmy się temu z bliska, analizując pierwsze dziesięć rozdziałów Księgi życia.

Przyjaźnie Teresy w okresie dzieciństwa i młodości ograniczają się zasadniczo do kręgu osób z najbliższej rodziny. W tym czasie szczególnie głęboką relację nawiązuje ze starszym o trzy lata bratem Rodrygiem: „Jego kochałam najbardziej, choć do innych wielkie miałam przywiązanie i oni do mnie" $(1,4)$. Nie wszystkie jednak przyjaźnie rodzinne były tak piękne i heroiczne. Z niektórymi kuzynami i kuzynkami, którzy odwiedzali jej rodzinny dom, miała stosunki bardziej powierzchowne, a nawet płoche i próżne. Niezbyt dobrze więc wspomina tamten czas $(2,2-3)$. Widzi bowiem, że nie rządziła nią wówczas subtelna świadomość reguł przyjaźni, lecz raczej nieujarzmiona jeszcze potęga naturalnego żywiołu: „Dla zrobienia im przyjemności podtrzymywałam z nimi rozmowę o wszystkim, o czym oni mówić lubili, słuchając z zajęciem, co mi opowiadali o upodobaniach i dzieciństwach swoich, niekoniecznie dobrych" $(2,2)$. Rodzaj tych relacji określi po latach w kategoriach moralnych jako szamotanie między „złym a dobrym towarzystwem” (2, 4-5); „towarzyskie owe stosunki i zabawy moje - dopowie, jakby reasumując - były $z$ rodzaju tych, które d rogą z a męś cia mogą doprowadzić do uczciwego rozwiązania" $(2,9)$. W języku Teresy oznacza to, że jej żywa i gorąca miłość rozwijała się raczej w kierunku małżeństwa aniżeli duchowej przyjaźni. W języku etyki greckiej była to bardziej miłość eros aniżeli philia. W każdym razie nie były to dojrzałe przyjaźnie. Były

59 Platon, Państwo, 504D. 
w nich co prawda ukryte wielkie tęsknoty, marzenia, pragnienia, ale nie miały one żadnej wewnętrznej siły i nie prowadziły do żadnych pozytywnych wyborów. Groziło im nawet całkowite rozpłynięcie się i unicestwienie.

Wszystko rzeczywiście mogłoby się potoczyć w ten sposób i Teresa nawet do końca życia mogłaby pozostać sfrustrowana i niezrealizowana w przyjaźni, gdyby w rozwiązywaniu wewnętrznych napięć, z jakimi sama sobie nie radziła, nie przyszły jej wówczas z pomocą inne osoby: najpierw starsza, przyrodnia siostra, odznaczająca się wielką dobrocią serca, która zostawiła jej dyskretny, niemniej jednak bardzo wyrazisty przykład życia „niepospolicie cnotliwego” $(2,3)$; następnie ojciec, z którym stale utrzymywała otwarte i pełne wzajemnego zaufania relacje, ale który w sytuacji konieczności potrafił również zdecydowanie interweniować i doprowadzić do umieszczenia córki w klasztorze w celu uchronienia jej przed grożącymi jej niebezpieczeństwami $(2,6)$; w końcu dojrzała i bardzo życzliwa zakonnica, z którą prowadziła długie, „święte rozmowy” o Bogu, przynoszące jej wiele światła i uwalniające ją od "grzesznych nawyknięć”, których wcześniej nie była świadoma ( $3,1-2)$.

W pierwszych dwudziestu latach życia zakonnego, od chwili wstąpienia do klasztoru aż do nawrócenia (1535-1554), czyli do trzydziestego dziewiątego roku życia, wewnętrzne napięcia i walki o właściwy charakter przyjaźni nie ustają. W tym czasie jednak Teresa już sama musi brać odpowiedzialność za siebie i rozwiązywać problemy na własną rękęe. W jej najgłębszym przekonaniu wszystko sprowadza się, bądź musi się sprowadzić, do jednego prostego wyboru: albo przyjaźń z ludźmi, albo przyjaźń z Bogiem. Innej opcji nie ma. W świetle jej wiary, na płaszczyźnie teologicznej, nie ma miejsca na rozwiązania pośrednie, połowiczne. Nie ma dla nich również miejsca na płaszczyźnie racjonalnej, filozoficznej.

W praktyce, oczywiście, te radykalne, młodzieńcze jakoby tylko przekonania stają się przyczyną wielu bolesnych doświadczeń i wewnętrznych konfliktów. Toteż Teresa jest wciąż rozdarta: „Im bardziej zbliża się do Boga, tym większy ogarnia ją lęk, iż będzie pozbawiona miłości ludzkiej, a im bardziej zbliża się do ludzi, tym trudniejsza staje się jej relacja z Bogiem"60. Próbuje więc sama szukać psychologicznej równowagi pomiędzy dwoma różnymi rodzajami miłości: do Boga i do ludzi. Próbuje łagodzić wewnętrzne napięcia na drodze intelektualnych syntez. Te doraźne rozwiązania nie przynoszą jej jednak spodziewanego pokoju i nie satysfakcjonują. Nie może ich nawet nazwać rozwiązaniami. Jej serce pragnie czegoś więcej i wciąż jest niespokojne. Wciąż bowiem brakuje jej harmonii między przyjaźnią z Bogiem a przyjaźnią z ludźmi, a z drugiej strony, nie może zdobyć się na radykalny wybór między nimi.

60 A. SICARI, Contemplativi per la Chiesa. Litinerario Carmelitano di S. Teresa di Gesü, Roma 1982, s. 60 (tłum. własne). 
Historię swoich wysiłków zmierzających do zaprowadzenia harmonii między tymi dwoma rodzajami miłości Teresa przedstawia na licznych przykładach. Niektóre zasługują na szczególną uwagę. W pierwszej kolejności rzuca się w oczy wielka przyjaźń łącząca ją z Juaną Juarez (Suarez), zakonnicą z klasztoru Wcielenia. Teresa nazywa ją swoją „serdeczną przyjaciółką” $(3,2)$, przyjaciółką, którą „kochała serdecznie” $(4,1)$. Motywem decydującym o wstąpieniu Teresy akurat do klasztoru Wcielenia jest uczucie, jakie żywi do Juany: „Gdybym miała być zakonnicą - zwierza się na kartach Księgi życia - nie chciałabym nią zostać gdzie indziej, jak tylko tam, gdzie ona przebywała". Zaraz jednak wskazuje na istniejący w niej samej problem: „Więcej miałam na myśli marną pociechę własną i skłonność przyrodzonych uczuć niż istotne dobro swojej duszy" $(3,2)$. Nie można tu nie zauważyć przeciwstawienia, jakiego dokonuje Teresa. Z jednej strony mówi o „skłonnościach przyrodzonych uczuć” (dokładnie: el gusto de mi sensualidad), a z drugiej o "dobru swej duszy” (lo bien que me estaba a mi alma). Niemniej Teresa wstępuje do klasztoru z tymi nieco „mieszanymi uczuciami”, a relacja między dwiema przyjaciółkami z czasem się pogłębia. Juana towarzyszy Teresie w jej długim pobycie leczniczym poza klasztorem, najpierw w Castellanos de la Cañada, a później w Becedas, gdzie cierpi na niewyjaśnioną do dzisiaj chorobę i niemal ociera się o śmierć $(4,5)$.

Właśnie w czasie trzymiesięcznego pobytu w Becedas ma miejsce spotkanie Teresy z pewnym kapłanem, które uwidacznia jej, na czym polega jej problem. Kapłan ów, „mąż bardzo dobrego rodu i bystrego rozumu” (5,3), u którego dwudziestoczteroletnia Teresa zaczyna się spowiadać, prowadzi jednak grzeszny styl życia. Od lat pozostaje pod wpływem pewnej kobiety, z którą utrzymuje świętokradczą relację i w żaden sposób nie potrafi się od niej uwolnić: „nieszczęsna owa kobieta wymogła na nim, aby dla miłości jej nosił na szyi jakiś bałwanek miedziany, do którego była przywiązała czary" $(5,5)$. Od pierwszego spotkania bardzo polubił Teresę. Wprawdzie jego miłość do niej „nie była grzeszna”, jednak „przez zbytnią czułość mogła się stać niedobra” $(5,4)$. Teresa jest bardzo zdeterminowana i „nigdy za nic na świecie nie zgodziłaby się obrazić Boga w rzeczy ważnej" (tamże). Takie niewzruszone stanowisko budzi w nim jeszcze więlksze do niej przywiązanie $(5,6)$. Wszystko kończy się szczęśliwie: kapłan ów pod wpływem pełnych zapału słów Teresy o Bogu i stanowczych jej działań zrywa z grzechem i jedna się z Bogiem. Paradoksalnie jednak, cały problem nie leży po stronie kapłana, lecz po stronie Teresy. Ona sama tak go ujmuje:

W wielkiej lekkomyślności i ślepocie swojej za cnotę to sobie poczytywałam, że okażę się jemu wdzięczną i wierną mu pozostanę za jego dla mnie przyjaźń i życzliwość. Przeklęta taka wierność, która posuwa się a $\dot{z}$ do sprzeniewierzenia się prawu Bo$\dot{z}$ e $\mathrm{m} u$ ! Jest to przewrotny obyczaj świata, na którego wspomnienie wszyst- 
ko się we mnie przewraca. Boć wszystko, cokolwiek ludzie nam uczynią dobrego, Bogu zawdzięczamy. A my za cnotę sobie poczytujemy nie zrywać przyjaźni ludzkiej, chociażby była obrazą Boga! Oślepoto świata! $(5,4)$.

Sedno problemu Teresy polega na tym, że chociaż ma dobre intencje i chce zrealizować dobry cel, to jednak do jego osiągnięcia posługuje się złymi środkami: „Zamiar mój był dobry, ale uczynek zły; bo dla dobrego celu, chociażby był najlepszy, nie godziło mi się uczynić najmniejszego zła" $(5,6)$. W konkrecie: chce pomóc zagubionemu kapłanowi, ale środki, jakie w tym celu stosuje, świadczą, że jeszcze nie potrafi tego czynić dobrze. Czynnikiem determinującym w tej relacji jest bowiem interesowna wymiana uczuć z partnerem: kapłan darzy ją sympatią i Teresa próbuje to uczucie odwzajemnić. W takiej zaś relacji zawsze występuje pewne „mniej-więcej”, pewna zwodniczość, chęć przypisania sobie za dużo albo za mało, byle tylko nie stracić partnera, mieć go dla siebie. I rzeczywiście, Teresa bierze za cnotę przyjaźni składane pod wpływem uczuć obietnice i przyrzeczenia, gdy tymczasem tego rodzaju deklaracje są co najwyżej zwodniczym igraniem, ważeniem, handlem, stawianiem na jednej szali tego, co w rzeczywistości ma różną wartość, nalepianiem etykiety jakiegoś towaru na opakowaniu, które zawiera coś innego. Teresa zwodzi/uwodzi nieświadomie, gdyż jeszcze nie odróżnia wyraźnie przyjaźni z Bogiem od przyjaźni z człowiekiem, jeszcze nie jest gotowa na dokonanie fundamentalnego wyboru, jeszcze nie potrafi zerwać ze światowymi obyczajami (wagami, ciężarkami). Jej cnota nie ma jeszcze totalnego oparcia w Jedynym Przyjacielu.

W końcowej części Księgi życia, spoglądając już z duchowych wyżyn na własną przeszłość, nawiąże wprost do tej swojej jeszcze kruchej kondycji duchowej i powie jednoznacznie, że „była to wada” (przeciwieństwo cnoty), która bardzo krępowała jej duchowy postęp: „Wada ta była taka: ile razy spostrzegłam, że ktoś przypadający do mojego usposobienia przychylnie ku mnie się skłania, takim zaraz do tej osoby przejmowałam się przywiązaniem, że serce i pamięć miałam w niej jakby u wi ę z i o n ą i ciągle prawie o niej myśla-

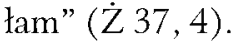

Okrutna, trwająca osiem miesięcy choroba, spotkanie niemal twarzą w twarz ze śmiercią i później powrót do klasztoru, w którym doświadcza nowego zalewu łask, danych jej dla rozwoju modlitwy wewnętrznej (por. rozdz. 6), nie usuwają jednak zasadniczego problemu, jaki ujawnił się podczas spotkania z kapłanem w Becedas. Przyczyną tego godnego ubolewania stanu rzeczy jest cały czas to, iż nie wyrywa zła $z$ korzeniem, nie zrywa związków uczuciowych, nie porzuca okazji i w dalszym ciągu kultywuje dawne, coraz bardziej krępujące ją przyjaźnie $(6,4)$. Spowiednicy i przełożeni nie dopatrują się w tych relacjach żadnego zła, całkowicie jej ufają i zostawiają pełną swobodę $(7,2.7)$. Prawie salonowy klimat 
klasztoru, otwarty na ciągłe światowe rozmowy, bynajmniej nie sprzyja zmianie stylu życia. Ona sama, bogato obdarzona przez naturę, pełna wdzięku i łatwo dająca się lubić, przyjmuje niekończące się odwiedziny bliskich jej osób, pochodzących z różnych sfer społecznych: „Poczęłam więc wdawać się w te rozmowy, bo widząc, że to zwyczaj przyjęty, nie sądziłam, bym odniosła z nich taką szkodę i roztargnienie na duszy, o jakich się później przekonałam" $(7,6)$. Z punktu widzenia moralności i przyjętych w klasztorze zasad postępowania spotkania te i rozmowy rzeczywiście mogły być określone jako nienaganne i pożyteczne, a same związki przyjaźni - nawet jako humanizujące. Takie mniemanie mogło być też podsycane przez głęboko humanistyczny klimat wytworzony przez renesans.

Teresa jednak nosi w sobie jeszcze inne, głębsze kryterium, które raz po raz daje o sobie znać i niepokoi ją: jest nim Pierwszy Przyjaciel, Najwyższe Dobro. Od pierwszych stron Księgi życia wyraża świadomość Jego istnienia i konkretnej obecności. Wie, że jest On nie tylko jakąś wzniosłą ideą Dobra, ale żywą Osobą, która jest dobra i realnie działa w jej życiu, chce ją obdarzyć swoją przyjaźnią: „Niczego nie zaniechałeś, abym od pierwszego dzieciństwa mego c a ł a była Two ja” $(1,8)$. Wie też i to: „Gdybym Ci się choć w cząstce odwdzięczyła za miłość, jaką mi poczynałeś okazywać, nie byłabym mogła ni ko m u oddać miłości swojej, je no Tobie sa memu, a miłość Twoja byłaby wszystko naprawiła" $(4,4)$. Niestety, jej życie zdominował wymiar horyzontalny. Wertykalny natomiast - pozostał za mgłą, zniknął z pola widzenia, przestał być zasadniczym punktem odniesienia. Pozwoliła rozproszyć się dobrym pragnieniom miłości, a zmienne formy przyjaźni zniewoliły jej serce. „Wielkie miałam do niej przywiązanie" (mucha aficción) - pisze o jednej z takich nieuporządkowanych, a bardzo szkodliwych dla jej duszy przyjaźni $(7,7)$. Całość natomiast dotychczasowych zmagań z uczuciami i walki o prawdziwą przyjaźń tak podsumowuje: „Nurzałam się blisko dwadzieścia lat w tym morzu burzliwym [ uczuć], wciąż upadając, to znów podnosząc się, i to słabo tylko - i potem znowu upadając i wiodłam życie przeciętne i dalekie od doskonałości" $(\dot{Z}$ 8, 2).

Nie odpowiedziała $z$ wdzięcznością całą sobą na miłość Pierwszego Przyjaciela. A ponieważ rzecz jest doprawdy wielkiej wagi, podkreśla to dwukrotnie na początku i na końcu opowieści o tym etapie swego życia: „Nie byłam cała w tych dobrych pragnieniach" (el no haber yo estado entera en los buenos deseos; $1,7)^{61}$; „czułam siebie skrępowaną i bezsilną do mężnego postanowienia oddania się Bogu bez podziału" (a darme del todo a Dios; 9, 8). Widzi, że rozbiła swoje życie na drobne cząstki. W dalszym ciągu jednak niesie mocne poczucie nienasycenia własnej potrzeby przyjaźni.

61 Tłumaczenie polskie ks. bpa Kossowskiego nie wyraża istoty problemu: „nie wytrwałam w tych dobrych pragnieniach". Brakuje w nim istotnego słowa "cała” (entera). 
Sytuacja ta, paradoksalnie, ujawnia najbardziej autentyczne pragnienia jej serca i otwiera oczy na Pierwszego Przyjaciela. Zaczyna wid zieć. Ukazują się jej postaci i formy przyjaźni, których wcześniej nie dostrzegała i nawet sobie nie wyobrażała, że mogą mieć coś wspólnego z przyjaźnią: „Ukazał mi się Chrystus Pan, stając przede mną z bardzo surowy m obliczem i oznajmiając mi przez to, jak te świeckie rozmowy moje Go zasmucają" $(7,6)$. Jak na ironię, zauważa je w trakcie zawiązywania kolejnej znajomości, doznając przyjemności, które zaspokajały jej próżność. Nie jest przypadkiem, że właśnie w tym kontekście Teresa używa (po raz pierwszy) wyrażenia „oczy duszy” (ojos del alma), które doskonale odpowiada platońskiemu poglądowi o noetycznych, czyli ponadzmysłowych, poznawczych zdolnościach duszy ${ }^{62}$. Podkreśla mianowicie możliwość realn e go widzenia nie tylko zmysłami, ale również umysłem: „Widziałam Go o c zy ma d u s zy jaśniej, niżbym Go widzieć mogła oczyma cielesny mi, i widok ten tak wyryty pozostał w pamięci mojej, że dziś jeszcze, po upływie więcej niż dwudziestu i sześciu lat, zdaje mi się, że mam Go przed sobą obecnego" $(7,6)$. Gdyby wyznanie to miało się okazać niewystarczająco zrozumiałe i w ogóle mało wartościowe dla materialistycznie i antyplatońsko nastawionych czytelników jej pism, jedno zdanie dalej Teresa tłumaczy: „Bardzo mi w tym zdarzeniu zaszkodziło, że nie wiedział a m o tym, iż można widzieć rzeczy inaczej niż samymi tylko oczyma ciała" $(7,7)$. Niewiedza ta jej zaszkodziła-Teresa bowiem okazała się recydywistką w złych przyjaźniach.

A że jest to niewiedza głęboka jak otchłań i wciąż pogłębiana przez wyobraźnię, która w nieskończoność potrafi karmić ludzkie ego złudnymi pociechami i mamić je namiastkami rzeczywistości, musiała się o tym boleśnie przekonać jeszcze nie raz i nie dwa. Nawet zapisane w rozdziale 9, a więc już pod koniec pierwszej części Księgi życia, słynne „widzenie” Jezusa "całego okrytego ranami” - na którego widok jej „dusza wstrząsnęła się do głębi”, zaczął ją trawić „żal na myśl, jak źle odwdzięczyła się za te rany”, „serce w niej pękało” i została rzucona „na kolana” $(9,1)$, i które zdawało się już definitywnie ją przemieniać - nie było widzeniem oczyma duszy żywego Jezusa i nie powodowało ostatecznego nawrócenia (chociaż za takie po dziś dzień jest ono uważane przez wielu jej czytelników). Patrzyły tu jeszcze oczy ciała na „wiernie oddaną" statuę Jezusa, działała wyobraźnia, kojone były emocje, potwierdzane osobiste ego. Teresa nie dostąpiła jeszcze łaski widzenia $\dot{z}$ y wej o soby Przyjaciela. Zmysłami w dalszym ciągu szukała pociechy na zewnątrz u ludzi i niezauważalnie przywiązywała się do kolejnych osób.

62 Por. np. Fedon, 65 A-D; 79 C-D; Uczta, 219 A; Fajdros, 263 C; Państwo VII, 519 B, oraz w niniejszym artykule punkt 2.1.1, gdy mowa o plat on sk i ch zdolnościach widzenia „oczyma duszy”. 


\subsubsection{Kontemplacja Jedynego Przyjaciela}

Zasługa wspomnianego przed chwila „widzenia” było jednak to, że poddała się mocy modlitwy: „Od tego czasu począł róść we mnie pociąg do dłuższego pozostawania z Bogiem i pilność w uchylaniu się od okazji, bo za usunięciem ich dusza od razu zwracała się do miłości Jego" $(9,9)$. Było to doświadczenie tak mocne, że w rozdziale 10 Księgi życia przerywa nagle opowiadanie biograficzne, skupione na dziejach swoich zmagań z wieloma ludzkimi przyjaźniami, i rozpoczyna pisać drugą część dzieła, poświęconą modlitwie, którą rozumie jako „przebywanie sam na sam [a solas] z Tym, o którym wiemy, że nas miłuje" (Ż 8,5). Już na pierwszy rzut oka widać, że rozdziały drugiej części (11-22) różnią się stylem od rozdziałów części pierwszej (1-10). Ale tylko nieuważnemu czytelnikowi może się wydawać, że mamy tu do czynienia $z$ drastycznym urwaniem myśli i podjęciem zupełnie odmiennej tematyki; albo że zostały już zakończone rozważania filozoficzno-egzystencjalne o przyjaźni, a rozpoczęte kwestie o charakterze ściśle teologicznym, przeznaczone dla ludzi wyłącznie wierzących. W rzeczywistości Teresa nie pisze klasycznego traktatu o modlitwie i praktykach modlitewnych. W dalszym ciągu pisze his torię swojej przyjaźni, która jest jedną długą wędrówką od wielu przyjaciół do Pierwszego Przyjaciela. Przy czym w pierwszej części akcent pada na „wielu”, w drugiej natomiast na „Jednego", albo na „sam na sam” z Przyjacielem. I ta druga część jest opowiedziana z innego punktu widzenia.

Chcąc zrozumieć ów punkt widzenia, odwołajmy się do platońskiej metafory słońca, która - jak już widzieliśmy - pomaga nam nie tylko odkryć ślady Dobra we wszechświecie, ale również zrozumieć samo Dobro. Podkreślmy, że św. Teresa od Jezusa w swoich pismach wielokrotnie odwołuje się do tej metafory ${ }^{63}$. W moim przekonaniu stanowi ona $\mathrm{klucz}$ in ter pretacy jny, umożliwiający również zrozumienie tego, co dokonało się w Teresie po widzeniu Jezusa "całego okrytego ranami”, oraz - na poziomie redakcyjnym - odkrycie powiązań między pierwszą (1-10) a drugą częścią (11-22) terezjańskiej Księgi życia. Łączac oba te poziomy, literacki z egzystencjalnym, w wielkim uproszczeniu możemy powiedzieć, że w pierwszej części Teresa przygląda się swoim relacjom przyjaźni z ludźmi w świetle słońca - i jest to stosunkowo łatwy ogląd, gdyż im więcej światła, tym rzeczy są lepiej widoczne; w drugiej części natomiast odważa się spojrzeć w s a mo słoń ce - a takie spojrzenie jest już czymś znacznie trudniejszym, prawie nienaturalnym, a w każdym razie nie jest tym samym, co patrzenie na inne rzeczy w świetle słońca. Stąd rozumiemy, dlaczego Teresa tyle miejsca poświęca w swoich pismach tematowi modlitwy.

63 Por $\dot{Z}$ 19, 2; 20, 19.28; 30, 14; T I, 2, 1.3.8; VI, 3, 18; 5, 9; 9, 4; VII, 1, 3; 2, 6. 
W języku filozoficznym możemy powiedzieć, że Teresa jest już blisko samych źródeł istnienia prawdziwej przyjaźni; staje twarzą w twarz wobec Tego, który jest Dawcą przyjaźni trwałej, niezawodnej, niepodległej ziemskim zmiennościom i nietarganej przez kapryśne namiętności; rozpoznaje nigdy niezbadaną istotę „Dobra samego w sobie”. Od zawsze jest ukierunkowana na Dobro, od dawna poddaje się żmudnemu procesowi oczyszczenia zmysłów i ducha, w promieniach Dobra rozumie już dobrze otaczającą ją rzeczywistość i samą siebie, ale - jak sama stwierdza - „nie rozumiałam jeszcze, jak powinnam była rozumieć, na czym się zasadza prawdziwa miłość Boga” $(9,9)$. Na modlitwie próbuje więc spojrzeć w oczy samej Miłości. Niesie głębokie przekonanie, że modlitwa nie jest w pierwszym rzędzie zewnętrzną praktyką, powinnością ani też rytualnym tylko kultem, lecz jest przede wszystkim r el acją przyjaźni (tratar de amistad; 8, 5). Począwszy więc od rozdziału 11, nie rozgląda się już wokół siebie, nie analizuje swoich międzyludzkich relacji, nie zagląda nawet w zakamarki swojego serca, chociaż introspekcja zawsze stanowiła jej mocną stronę i, idąc w ślady swojej epoki, nigdy z niej nie zrezygnuje. Przez praktykę modlitwy wewnętrznej chce jednak wyjść poza siebie, poza samolubną ludzką jaźń, na której tak bardzo koncentrują się wszystkie współczesne nauki o człowieku. Chce przyzwyczajać swój wzrok, by móc patrzeć wyłącznie w słoń ce: czyni siebie „niewolnikiem miłości”, to znaczy zaczyna wchłaniać w siebie promień po promieniu i asymilować naturę Tego, który jest samą Miłością i „tak bardzo nas umiłował” (tanto nos amó; 11, 1).

W tym samym numerze rozdziału 11 zwraca się do Boga z charakterystycznym dla siebie zawołaniem modlitewnym: „O Panie duszy mojej, jed yne dobro moje". Widzenie Dobra rodzi w niej doświadczenie wewnętrznej i zewnętrznej jedności. Jednocześnie jednak zostaje jakby porażona promieniami słońca i zauważa coś, co zdaje się podważać podstawowe prawo przyjaźni (condiciones) - mianowicie wielką dy s p r o po r c ję, nierówność, dystans między bezmierną miłością Boga a naszą nędzną miłością. Zwróciła na to wszystko uwagę już wcześniej, gdy podawała definicję modlitwy jako „przyjacielskiego z Bogiem obcowania" (tratar de amistad; 8, 5). Tam jednak różnicę tę uwydatniła przez kontrast między doskonałą naturą boską, której nic nie brakuje, a naszą naturą, która jest „skażona, zmysłowa i niewdzięczna”; i podkreśliła, że różnica ta jest niwelowana przez samego Boga, który w swej miłości pochyla się nad człowiekiem i jak „prawdziwy przyjaciel” cierpliwie znosi niskość tego, który nie umie znieść wysokości Boga $(8,6)$. Tutaj natomiast, w rozdziale 11, skupia się bardziej na działaniu człowieka i zastanawia się, co może i powinien on uczynić ze swej strony względem Boga, aby zadośćuczynić wymogom przyjaźni i zbliżyć do siebie tak bardzo oddalone od siebie bieguny. I zauważa, że niestety „nie ma na ziemi żadnej rzeczy tak kosztow nej i drogi ej, by mogła starczyć na okupienie tak wielkiego dobra" $(11,2)$, jakim jest miłość Boga. 
W czasach św. Teresy od Jezusa ta metafizyczna różnica między Bogiem i człowiekiem, niebem i ziemią, była jeszcze czymś oczywistym i ogólnie przyjętym. W naszej natomiast samowystarczalnej, konsumpcyjnej i demokratycznej kulturze o wiele trudniej ją uchwycić i egzystencjalnie przeżyć, a zatem - łatwiej zignorować. $Z$ jednej bowiem strony, przyzwyczailiśmy się do patrzenia na dobra tej ziemi prawie wyłącznie w świetle słońca naturalnego i żyjemy w złudnym przekonaniu, że jedynie one istnieją, a wszystko inne jest mrzonką i fikcja; traktujemy je po przyjacielsku, czasami oddajemy im bałwochwalczy pokłon, sycimy nimi naszą duszę i już nie zauważamy, że często są to jedynie sobowtóry prawdziwego Dobra, które powoli odbierają nam świadomość naszej skończoności, poczucie umiaru i wolność. $Z$ drugiej strony, nie potrafimy, jak wielcy mistycy, Platon, Teresa, otworzyć oczu na samo Dobro i skonfrontować się z nim jako czymś ontologicznie całkowicie innym; nie jesteśmy w stanie dostrzec, że całe jego piękno i siła leżą nie w zewnętrznych i ulotnych fenomenach, lecz w jego absolutnej nagości, samotności, milczeniu, bezinteresowności, bezbronności, które są „nie z tego świata”; nie zauważamy też, iż w tych właśnie jego cechach zawarta jest idealna, to znaczy boska miara naszego człowieczeństwa.

Platon i Teresa tymczasem, chociaż mają bardzo odmienne wizje Boga (por. punkt 2.2.1), nieodmiennie wpatrują się w boskie słońce Dobra i w jego zdolność urzeczywistniania jedności-w-wielości - urzeczywistniania przyjaźni. Szukają doskonałej miary nie na drodze genetycznej-w rozchwianych uczuciach, w których zawsze występuje „mniej-więcej”, lecz na drodze k ontem placji - w niezawodnym i stabilnym Dobru. Jedynie taka miara ich satysfakcjonuje. W centralnej części platońskiego Państwa czytamy: „Ach, przyjacielu - odpowiedziałem - miara w takich rzeczach, jeżeli choć trochę odbiega od tego, co jest, to nie jest miara w samą miarę. Co nie jest doskonałe, nie jest żadną miarą dla niczego" ${ }^{4}$. Teresa natomiast, odnosząc do swojego Boga grecką kategorię doskonałości, pisze z kolei tak: „W Panu Bogu, najwyższym Dobru naszym [en nuestro sumo Bien], nic nie może być, co by nie było doskonałe, więc i miara, jaką daje nam tę wodę [ swojej przyjaźni], musi być doskonała, to jest doskonale odpowiadająca naszym potrzebom" (D 19, 9). Doskonała przyjaźń Boga wobec nas wyraża się, według niej, między innymi i paradoksal-

64 Państwo, 504 B-D. W dialogu Gorgiasz Platon mówi wręcz o „równości geometrycznej”, która stanowi podstawę wszelkiego „związku”, „wspólnoty”, „przyjaźni”: „R ó w n o ść geometryczna i u bogów, i u ludzi wielkąmoc posiada. A ty[Kaliklesie] myślisz, że trzebasięćwiczyćw posiadaniu więcej niżdrudzy. Za mało pamiętaszo ge o metrii" (508 A). Kwestia „równości geometrycznej” jest istotna dla mistyków karmelitańskich W drugiej części pracy zobaczymy jej konk retne przykłady u św. Teresy od Jezusa, choć św. Jan od Krzyża przykłada do niej jeszcze większą wagę. Dziś prawie jej nie zauważamy w ich pismach! 
nie w tym, iż nie pozwala On, abyśmy od razu stali się Jego przyjaciółmi i mieli udział we wszystkich Jego dobrach $(\dot{Z} 11,1-3)$. W przyjaźni wszakże ważne jest, aby uczyć się precyzyjnie rozróżniać rzeczy, cenić sobie dobra przyjaciela, szanować odpowiedni dystans i absolutnie nie zgłaszać żadnych roszczeń. Wszystko w niej jest „darem”. Trzeba się tylko ściśle poddać logice tego daru. Dlatego w ogóle „bardzo wielkie miłosierdzie czyni Bóg temu, ko$\mathrm{mu}$ d a ła skę, męstwo i skuteczne postanowienie dążenia ze wszystkich sił do osiagnięcia tego dobra [este bien]" $(\dot{Z} 11,4)$.

Nie jesteśmy w stanie prześledzić tutaj wszystkich praw bosko-ludzkiej przyjaźni zawartych w drugiej części Księgi życia (rozdz. 11-22) - jest to zresztą praca, która należy raczej do dziedziny teologii chrześcijańskiej. Niech nam zatem wystarczy świadomość, że opisana w niej historia przyjaźni nie jest historią błędnego rycerza z La Manchy, który wiedziony pragnieniem przygód i chęcią zaimponowania damie swego serca zdobywa się na szereg rzekomo heroicznych, ale w rzeczywistości pełnych patosu i przesady czynów (ekspresja bez miary). Jest to natomiast historia przyjaźni Boga z Teresą, którą to historią rządzi nie ślepa namiętność i przypadek, lecz boski Logos, wyrażony w „żelaznej logice absolutnej miłości" rodem z nieba, mającej swoje precyzyjne miary właś-nie w miłości Pierwszego Przyjaciela.

Podejmując się zadania opowiedzenia tej historii, Teresa zna już dobrze swojego Przyjaciela, zna całą logikę Jego miłości, ale zna również swoją ograniczoność, słabość i niestałość. Za pomocą pięknego obrazu ogrodu objaśnia więc swym czytelnikom, w jaki sposób powinni pracować nad swoimi duszami, aby wydały one właściwe owoce cnót, a jego kwiaty przyniosły boskiemu Przyjacielowi miłą woń, to znaczy - co należy czynić, aby w tym zmiennym świecie upodobnić się do niezmiennego w swej miłości Przyjaciela ${ }^{65}$.

Praca człowieka w tym dziele - mówi - jest ogromna. Najważniejszą jednak rzeczą jest sprowadzenie do ogrodu wody, która podobnie jak promienie słońca ma cechy życiodajne i wyobraża działanie Bożej łaski (nawet gdy jest sprowadzana działaniem człowieka). Obrazy wody i słońca (ognia), aczkolwiek na pierwszy rzut oka sobie przeciwstawne, pod koniec drugiej części Księgi życia całkowicie się ze sobą stapiają (por. rozdz. 18-21). Oba w końcu wyobrażają cudowną boską moc i ukazują jeden i ten sam skutek, a mianowicie - poddanie duszy ludzkiej działaniu boskich „亡̇ywiołów”, które same sprawiają, że dusza

65 „Upodobnienie się do Boga” (Pierwszego Przyjaciela) jestczymś istotnym również dla Platona Przyjmuje ono u niego strukture liczbową i w praktyce oznacza wprowadzanie boskiego porządku do nieporządku, boskiej miary do braku miary, jedności-do-wielości. Jeśli na serio potraktujemy metaforę słońca, okaże się, że jego wizja upodobnienia się do Boga jest w swojej dynamice stosunkowo bliska terezjańskiej: „upodobnić się do Boga (homoíosis theo) w takiej mierze, w jakiej jest to dla człowieka możliwe" (Państwo, 613 B) 
stopniowo się z nimi jednoczy, do nich się upodabnia i ostatecznie zostaje w nie przemieniona: „Woda, która zstępuje z nieba, swoją obfitością n a pełn ia i na syca cały ogród” (Z 18,9$)$; „Gdy [dusza] spojrzy na to Boskie Słońce, jasność jego olśniewa ją" $(\dot{Z}$ 20,29).

Pragnienie działania u Teresy nigdy nie ustaje. Jest ono obecne nawet na ostatnich stopniach modlitwy. Co więcej, ponieważ na tym etapie relacji widzi ona swego Przyjaciela już niemal "twarzą w twarz", więc i prawo przy jaźni staje się wówczas jeszcze bardziej naglące, jakkolwiek nie usuwa ono poczucia różnicy dzielącej ją od Przyjaciela: „Niech kiedy przyjdzie ten czas, bym zdołała Ci spłacić choć jaki gros z z tego wielkiego długu, który Ci jestem winna" $(21,5)$. Przypomnijmy w tym kontekście, że Platon, przyglądając się z wdzięcznością światłu idei Dobra, które jest mocniejsze niż światło wszystkich innych idei, miał bardzo podobne odczucie: zdawał sobie sprawę, że pisząc o Dobru, spłaca wobec niego jedynie „odsetki” - cały dług natomiast musi spłacić gdzie indziej i w inny sposób. U niego jednak stosunek do Dobra, mimo pełnego zaangażowania $z$ jego strony, ma charakter bezosobowy. U Teresy natomiast cieszy się wielkim przywilejem relacji osobowej. Stąd Teresa, przynaglona wspomnianym prawem przyjaźni, może się zwrócić do swego Przyjaciela w takich oto słowach: „Sam zrządź, o Dobro moje [Bien mio], jak zechcesz, i podaj sposób, aby Ci w czymkolwiek usłużyć mogła ta służebnica Twoja" (Ż 21, 5). I dwa zdania dalej, używając formuły typowo biblijnej (superlativus absolutus), ale słownictwa charakterystycznego również dla filozofii greckiej, dodaje: „O Dobro nad wszelkie dobra, o Jezu mój" ( $O$ Bien de todos los bienes y Jesús mio).

Ta ostatnia formuła zdaje się tworzyć doskonałą syntezę wszystkich naszych dotychczasowych rozważań. Kontemplacja Boskiego Słońca, Jezusa, z jednej strony rodzi w Teresie poczucie nieskończonej różnicy istniejącej między ziemskimi dobrami a Najwyższym Dobrem oraz, z drugiej strony, świadomość, że jedynie w Nim znajduje się niewyczerpane źródło prawdziwej przyjaźni. Odwracając kolejność tych dwóch rzeczy, możemy powiedzieć, że Teresa wie, iż tylko Jezus, „Dobro nad wszelkie dobra” ( ́́ r ó dło), obdarza ją nigdy niekłamaną przyjaźnią, ona natomiast, jeśli nie chce kłamać, powinna odpowiedzieć na Jego nieskończony dar darem $z$ samej siebie - co według niej jest „groszem” w porównaniu z zaciągniętym „długiem” (różn ica). Nie bez ironii więc mówi: „Gdyby za pieniądze można było kupić to dobro [tę przyjaźń!], k tó re te raz widzę w sobie, wysoko bym je [pieniądze] poważała; ale widzę, że dobra tego nabywa się wyrzeczeniem się wszystkiego". Nieco dalej, w tym samym numerze, aplikuje tę wielką prawdę do życia społecznego: „Jaką życzliwość i przyjaźń mieliby jedni dla drugich, gdyby znikły zoblicza ziemi te zabiegi o hon or i pieniądze!". I zaraz wyraża swoją wiarę 
w moc bezinteresownej przyjaźni: „Sądzę, że to je d no byłoby skutecznym lekarstwem na wszystko zło na świecie" (Ź 20,27).

Teresa nie tyllko wie, co mówi, ale mówi z samej głębi i - powtórzmy to jeszcze raz - w oparciu o własne doświadczenie. Po długich latach praktykowania modlitwy wewnętrznej i dostrajania swoich duchowych zmysłów i zamysłów do boskich miar (rozdz. 11-22) spotyka w końcu swojego Pierwszego Przyjaciela i doznaje upragnionej wewnętrznej przemiany. To wydarzenie pozwala jej oddać Mu całe życie, już bez fałszywego zatrzymywania czegokolwiek dla siebie, i otworzyć oczy na całą prawdę o Bogu, sobie i świecie. Nie jest przypadkiem, że o tym kluczowym spotkaniu i definitywnym nawróceniu opowiada dopiero w trzeciej części swej autobiografii, w której przedstawia „nowe życie”, jakie darmo wszczepił w nią właśnie ów Pierwszy Przyjaciel. Było to właściwie już nie jej życie, lecz Jego życie w niej (rozdz. 23-31). A przemiana ta - mówiąc konkretnie - dokonała się w następujący sposób. Pewnego dnia usłyszała na modlitwie Jego słowa: „Nie chcę już, byś obcowała z ludźmi, tylko z a ni ołami" ( $\dot{Z} 24,5)$. Teresa posłuchała słów Przyjaciela i sama przyznaje, jaki owoc one w niej zrodziły: „Od tego czasu nigdy juz nie zdołałam zawrzeć przyjaźni ani znajdować przyjemności, ani szczególną łączyć sięmiłością, jeno z takimi, w których widziałam miłość Boga nad wszystko i ochotną do słuźby Jego gotowość. Nie potrafię inaczej ani nie zważam na to, czy to krewni lub dawni przyjaciele" ( $\dot{Z} 24,6)$. To było rzeczywiście definitywne nawrócenie.

W czwartej i ostatniej części autobiografii (rozdz. 32-40), w której opisuje swoją „służbę miłości” wobec wspólnoty, a więc i wobec nas, znajdujemy tekst-perełkę, który stanowi nie tylko podsumowanie całej „długiej drogi” Teresy „od wielu przyjaciół do Pierwszego Przyjaciela”, ale jednocześnie podważa nasz współczesny (naukowy!) zabobon, głoszacy wszem i wobec, że wewnętrzny albo mentalny świat człowieka w sposób nieunikniony pasożytuje na świecie zewnętrznym i tym, co genetyczne, a więc że jesteśmy skazani na „wielość” i tylko na wielośćc6. Teresa mianowicie po przyjacielsku dzieli się z nami swoim doświadczeniem mocy kontem placji i prawdą, że tylko Bóg, Jedyny Przyjaciel, może zaprowadzić upragnioną jedność w różno rodności:

Odkąd dano mi było ujrzeć Bożą pięlkność Pan a mego, żadnej już nie masz śmiertelnej istoty, która by w oczach moich mogła $z$ nią w y tr zymać porównanie i myśl i serce me zająć. Jed no okiem wewnętrznym spojrzenie na ten obraz, który noszę wyryty w duszy, zupełną w tym względzie daje mi swobodę serca... $(\dot{Z} 37,4)$.

66 I. Murdoch, Prymat dobra, Kraków 1996. Autorka, opierając się na filozofii Platona, rozprawia się m.in z tym właśnie zabobonem. 


\section{ZAKOŃCZENIE (CZĘŚCI I)}

Na zakończenie naszych dotychczasowych rozważań możemy powiedzieć, że ich osią był Pierwszy Przyjaciel - Dobro samo w sobie. Długa droga wiodąca Platona i św. Teresę od Jezusa do spotkania tego Dobra - powiedzmy to trochę paradoksalnie i dla osobistego ćwiczenia się w pokorze! - nie przyniosła właściwie żadnych praktycznych i wymiernych rezultatów; przynajmniej takich, jakich spodziewa się przeciętny współczesny człowiek. Może nawet sam Arystoteles, wyglądając niecierpliwie z trzeciego rozdziału pracy, jaka nas jeszcze czeka, nie zawahałby się spojrzeć na nas z góry i kąśliwie powiedzieć, że wszystkie te rozważania o platońskich „ideach” i terezjańskim „darze” przyjaźni do niczego w praktyce nie są przydatne i spokojnie można je włożyć między bajki.

Według arystotelesowskiej filozofii bowiem, dostęp do Dobra jest możliwy dzięki ludzkiemu działaniu. Dobro jest tym, co czynimy, albo raczej powinniśmy czynić, i dlatego kontemplacja jest tu zbyteczna (choć Arystoteles w ogóle bardzo ją sobie cenił). Przyjaźń budowana jest przez konkretne czyny cnotliwe, a nie przez kontemplację. Dla życia moralnego i życia w przyjaźni w zupełności więc wystarczą zwykłe normy postępowania, albo, inaczej mówiąc, odpowiedź na pytanie: „Co mam czynić?”. Nie muszę zatem zdobywać się na żadną wzniosłą kontemplację i myśleć o jakimś wielkim Dobru - mogę w zupełności ograniczyć się do „dobra, które należy wykonać”.

Trzeba przyznać, że to rozumowanie jest jak najbardziej poprawne. Potwierdza je zresztą długa tradycja filozoficzna, w tym także chrześcijańska. Nic więc dziwnego, że ten właśnie filozof będzie ważnym towarzyszem naszych dalszych refleksji na temat etycznego aspektu przyjaźni (rozdział trzeci). W tym miejscu chcemy jednak zgłosić obiekcję wobec jego koncepcji dobra, zawężonego do „dobra, które należy wykonać”. Wydaje się bowiem, że tak rozumiane dobro, jeśli nawet jest wystarczające do wytworzenia konkretnych d z i a ł án moral$\mathrm{n}$ y ch, nie jest jednak wystarczajace dla wytworzenia pewnego rodzaju o s ob y, która stałaby się podmiotem życia moralnego i potrafiła w niezliczonych sytuacjach życiowych udzielić prawidłowej odpowiedzi na pytanie, co należy czynić.

Przekonanie o tej niewystarczalności wyraża w każdym razie francuski filozof Rémi Brague. Podzielając je w pełni, własną czynimy również jego konkluzję. Zgadzamy się mianowicie, że platońska „idea” i terezjański „dar” przyjaźni nic konkretnego nie „czynią” w moralnym postępowaniu, są leniwe, bezproduktywne, a więc w praktyce zbyteczne. „Może jednak dałoby się powiedzieć, że działają jak ka taliza to r w chemii: ich obecność niczego nie »dokonuje«, ale umożliwia, by to, czego one nie czynią, mogło być wykonane" ${ }^{67}$.

67 R. BRague, Ancore nel cielo..., s. 93 (podkreślenie i tłum. własne). 
Zapewne dałoby się również powiedzieć, że obecność osób i wspólnot (klasztorów) kontemplacyjnych, które całą swoją egzystencją poszukują Jedynego Przyjaciela, nie jest niezbędna, aby ludzkie postępowanie moralne było poprawne i nawet by były tworzone pewnego rodzaju związki przyjaźni. Może jednak ich obecność jest niezbędna, żeby w naszym świecie ludzie mogli zobaczyć przyjaźn nie z tego świata -bezinteresowną, samotną, milcząca, gotową oddać życie za przyjaciół...

Może konieczne jest świadectwo w rodzaju tych, jakie zostawił jeden ze współczesnych duchowych synów św. Teresy od Jezusa: „Przyjaźń przychodzi dopiero wówczas, gdy zaczynamy smakować milczenia, jakie nam towarzyszy"68.

68 P. Villarejo, Después de las campanas, Úbeda 2015, tekst z obwoluty (ttum. własne). 


\title{
RIASSUNTO
}

\author{
Albert Staniseaw Wach OCD \\ Verso la filosofia dell'amicizia. \\ Nel dialogo con Platone, Aristotele e Santa Teresa di Gesù
}

Il tema di questo articolo è l'amicizia, in greco filía, una delle forme più spirituali dell'amore umano. Nella cultura contemporanea, segnata dall'utilitarismo e dall'edonismo, l'amicizia non gode di ampio riconoscimento sociale. Non lo gode neppure nell'ambito dei filosofi professionali come lo godeva, per esempio, nell'antichità greca dove i filosofi scrivevano lunghi e saggi trattati su questo tema. Oggi, piuttosto, vengono privilegiate forme sensuali dell'amore (eros). L'amicizia invece rimane solitaria ed abbandonata. La finalità di questo studio è di ricuperarla dall'oscurità della dimenticanza e dalle false connotazioni.

In questo progetto così grandioso non siamo soli. $\mathrm{Ci}$ viene in aiuto la grande Tradizione e i suoi migliori rappresentanti: in questo caso Platone, Aristotele e Santa Teresa di Gesù. Essi non sono lontani spiritualmente tra loro e da noi come sembra a prima vista. Hanno in comune una buona conoscenza del tema, l'esperienza personale e soprattutto l'amicizia con saggezza: filo-sofia.

Il presente lavoro si divide in quattro capitoli dei quali due sono pubblicati in questo numero di Itinera Spiritualia. Nel primo capitolo, di carattere stori$c o$, intervengono tutti i partecipanti di una sorta di tavola rotonda sul tema dell'amicizia: in primo luogo siamo noi stessi a farci un problema del come essa si presenta nella nostra attualità; in secondo luogo Platone ed Aristotele ci illuminano dalla prospettiva dell'antichità greca e dalle loro proprie filosofie; in terzo luogo Santa Teresa, il legame tra queste due epoche porta un contributo originale e forte in base alla sua ricca esperienza umana in un'epoca che non è riuscita a definire filosoficamente la propria identità (il rinascimento).

Nel secondo capitolo, di carattere metafisico, rimangono solo i due dialoganti: da una parte Platone che presenta la sua "idea" dell'amicizia, e dall'altra parte Santa Teresa con la sua comprensione dell'amicizia come un "dono". Ci narrano il loro "lungo cammino" realizzato, da molte amicizie imperfette fino a incontrare il Primo Amico vero. Il Platone-filosofo lo fa utilizzando il metodo strettamente speculativo, però non gli manca l'esperienza mistica; Teresa-mistica invece si riferisce alle proprie esperienze personali, però non senza una solida base razionale metafisica. I due si incontrano nell'Uno-Bene. La loro testimonianza è molto importante per la cultura odierna.

Nel terzo e quarto capitolo sviluppo il tema dell'etica e del linguaggio dell'amicizia. 


\author{
ABSTRACT \\ Albert Staniseaw Wach OCD \\ Towards the Philosophy of Friendship. \\ In a Dialogue with Plato, Aristotle and St Teresa
}

The topic of the article is friendship, in Greek philia; one of the most spiritual forms of human love. In contemporary culture, marked with utilitarianism and hedonism, friendship is hardly appreciated on a wider social scale. This is true nowadays even in the elite circles of learned philosophers - in contrast, for instance, to the ancient Greek philosophers who wrote long and wise treatises about friendship. Today, the sensual forms of love tend to be highlighted (eros), while friendship remains isolated and forsaken. The present study aims therefore to liberate friendship from the darkness of oblivion and from false assumptions.

In this immense undertaking we are not alone. The Great Tradition comes to our aid with its outstanding representatives: in our case, with Plato, Aristotle, and St Teresa of Jesus. Contrary to what our first impression might be, they are not distant from one another in the spiritual sense. What they have in common is a thorough knowledge of the subject, personal experience and, most of all, friendship with wisdom: philo-sophy.

The entire text is divided into four chapters, two of which are published in the present issue of Itinera Spiritualia. In Chapter One, historical in its character, all participants of the debate on friendship voice their opinion: firstly, we raise the issue of the condition of friendship in the contemporary culture; secondly, Plato and Aristotle shed light on this issue from the point of view of ancient Greek philosophy in general, and their own philosophies in particular; finally, St Teresa, creating a link between our times and the ancients, provides original and significant input into how we understand friendship. She does this thanks to her wide experience (interestingly enough, an experience gained in the age of the Renaissance, which could not, philosophically speaking, define the identity of friendship).

In Chapter Two, of metaphysical character, only two participants in the friendship debate are included: on the one side, Plato, who presents his "idea" of friendship, and on the other side, St Teresa, with her understanding of friendship as a "gift". They reveal to us the "long path" which took them from many imperfect friendships to the meeting with the First True Friend. Plato the Philosopher employs a strictly speculative method, but he does not lack mystical experience; Teresa the Mystic, on the other hand, shares her personal friendship 
stories, but not without a substantial and rational metaphysical basis. They both meet in the One, the Good. Their testimony has an immense value for our contemporary culture.

In Chapter Three and Four, which will be published in next year's issue of Itinera Spiritualia, I deal with ethics and with the language of friendship.

Słowa klucze: filozofia przyjaźni, Platon, Arystoteles, św. Teresa, eros, „idea” przyjaźni, doświadczenie mistyczne

Keywords: philosophy of friendship, Plato, Aristotle, St Teresa, eros, "idea" of friendship, mystical experience 